\title{
Working
}

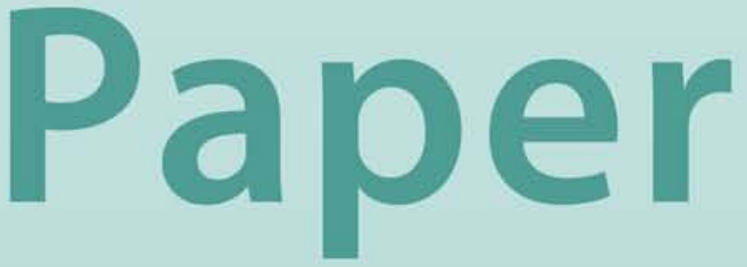




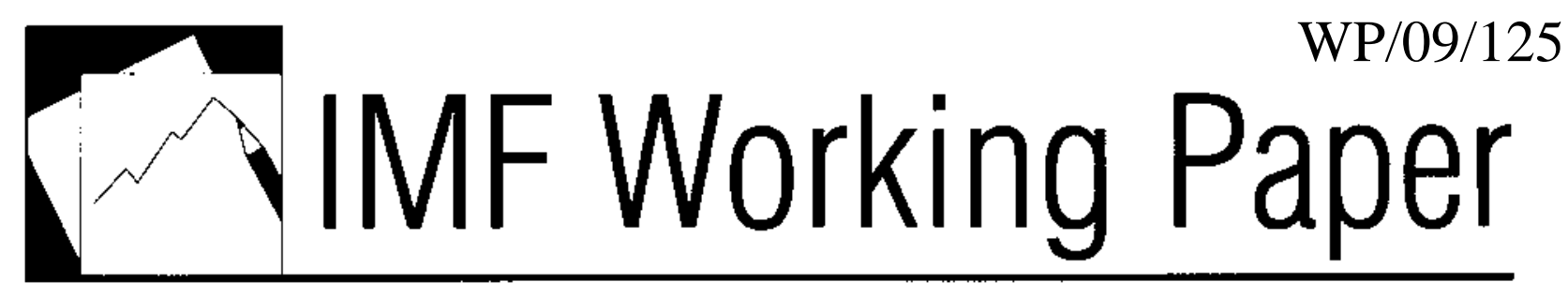

\section{Decoupling from the East Toward the West? Analyses of Spillovers to the Baltic Countries}

Kingsley I. Obiora 


\title{
IMF Working Paper
}

\author{
European Department
}

\section{Decoupling from the East Toward the West? Analyses of Spillovers to the Baltic Countries}

\author{
Prepared by Kingsley I. Obiora ${ }^{1}$
}

Authorized for distribution by James Morsink

June 2009

\begin{abstract}
This Working Paper should not be reported as representing the views of the IMF. The views expressed in this Working Paper are those of the author(s) and do not necessarily represent those of the IMF or IMF policy. Working Papers describe research in progress by the author(s) and are published to elicit comments and to further debate.
\end{abstract}

This paper uses VAR models to examine the magnitude and sources of growth spillovers to the Baltics from key trading partners, as well as from the real effective exchange rate (REER). Our results show there are significant cross-country spillovers to the Baltics with those from the EU outweighing spillovers from Russia. Shocks to the REER generally depress growth in the Baltics, and this intensifies over time. We also find that financial and trade channels dominate the transmission of spillovers to the region which partly explains the realization of downside risks to the Baltics from the global slowdown.

JEL Classification Numbers:C22, E32, F41, F43

Keywords: Spillovers, Baltics, Vector Autoregression

Author’s E-Mail Address: kobiora@imf.org

\footnotetext{
${ }^{1}$ I would like to thank James Morsink, Athanasios Vamvakidis, Gavin Gray, Nada Choueiri, Mame Astou Diouf, Andrew Swiston, Irineu de Carvalho Filho, and participants at the EUR Brown Bag seminar for helpful comments. I am also grateful to Alex Hoffmaister who provided general guidance on this paper.
} 


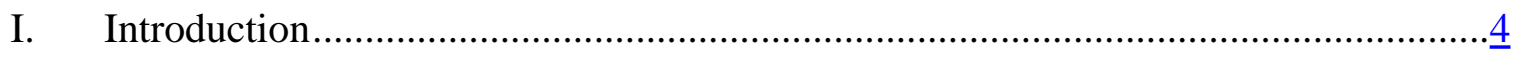

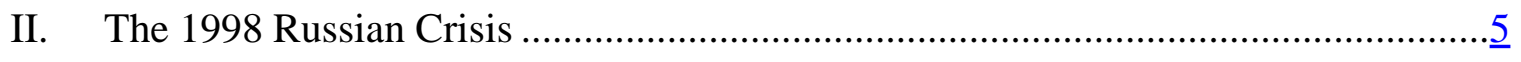

III. Trade and Financial Linkages ................................................................................

IV. Econometric Analysis .........................................................................................

A. Vector Autoregression Models .........................................................................12

B. Extended Vector Autoregression Models ..............................................................17

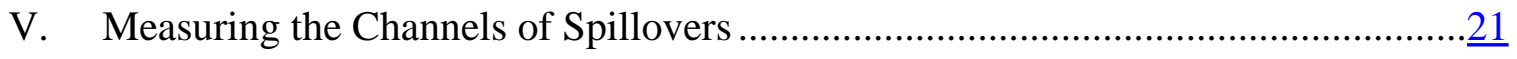

VI. Conclusions and Lessons for Policy ………………………………………….....

Tables

1. The Baltics: Sources and Destination of Foreign Direct Investment (in percent of total, 2007)........................................................................................................

2. Variance Decomposition for Baltic Countries' Real GDP (Base VAR Models)............................................................................................

3. Variance Decomposition for Baltic Countries' Real GDP

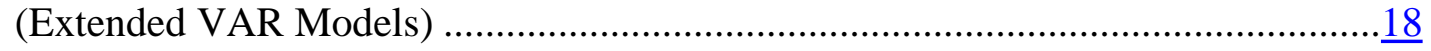

Figures

1. The Baltic Countries: Responses of Aggregate Demand Components to 1998 Russian Crisis (year-on-year change, in percent) ……………………………... $\underline{6}$

2. The Baltics: Exports and Imports of Goods and Services (in percent of total,

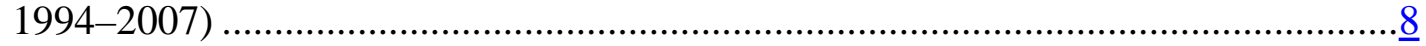

3 Baltic Countries: Business Cycle Synchronization with Major Trading Partners ....11

4. Baltic Countries: GDP Growth Responses to 1 Percent Shocks from Major Trading Partners and Real Effective Exchange Rate................................................16

5. Baltic Countries: GDP Growth Responses to 1 Percent Shocks from Major Trading Partners, Oil Price Growth and REER ....................................................................

6. The Baltic Countries: Contributions to Spillovers from EU Countries ......................23

7. The Baltic Countries: Contributions to Spillovers from Russia .................................24

8. The Baltic Countries: Contributions to Spillovers from the Scandinavian Region. 


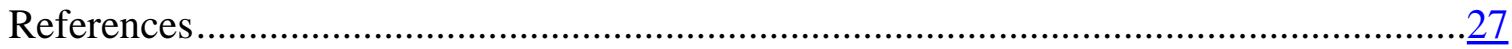

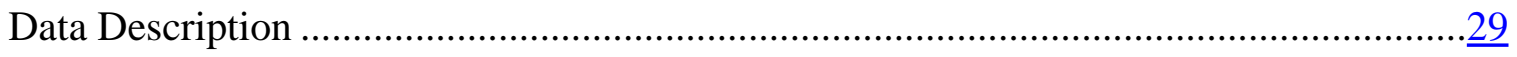

Appendices

Tables

A1. The Baltic Countries: Direction of Imports to Major Trading Partners (in percent of total) ...............................................................................................

A2. Structure of Bank Ownership in the Baltic Countries ..............................................

A3. Results of Unit Root Tests Using the Ng-Perron Procedure.........................................32

A4. Variance Decomposition Results (Base VAR Models, 1996-2007)...........................33

A5. Variance Decomposition Results (Extended VAR Models, 1996-2007)...................34

Figures

A1. The Baltic Countries: Decomposition of Exports and Imports (in percent

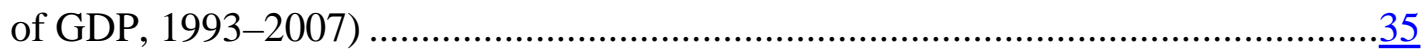

A2. Impulse Response Results (Base VAR Models, 1996-2007)....................................

A3. Impulse Response Results (Extended VAR Models, 1996-2007) ………………......37

A4. The Baltics: Responses to 1 Percent Shock from the Scandinavian Region ...............38 


\section{INTRODUCTION}

Given their historical and economic ties, Russia's 1998 economic crisis had significant consequences for the Baltic countries ${ }^{2}$. The crisis which was triggered by sharp declines in oil and commodity prices, and non-payment of taxes by major energy and manufacturing companies, affected the Baltic countries (Estonia, Latvia and Lithuania) through financial and trade linkages. Specifically, Baltic banks which invested heavily in Russia's short term treasury bills suffered significant losses following the country's debt default. Interest rates also rose sharply in Baltic interbank markets. In addition, there were significant declines in Baltic country exports to Russia given the sharp depreciation of the Russian ruble. As a result, all three Baltic countries recorded precipitous declines in GDP growth rates.

Since then, changes in trade linkages suggest some decoupling from the Russian economy towards the EU countries. The Baltic countries' trade with Russia has declined in the years after the crisis. Over the period 2000-07, exports of the Baltic countries to Russia have fallen by nearly 8 percent while exports to the EU countries have grown by an average of about 10 percent. Similarly, Baltic imports from Russia have fallen by an average of 4.2 percent while imports from the EU have risen by over 6 percent since the crisis. This trade expansion with the EU is concentrated in a few countries, namely, Germany, the UK, Poland and Sweden and Finland.

Foreign direct investment (FDI) in the Baltics is also increasingly tilted toward Europe. Especially since EU accession in May 2004 and the resultant increase in investors' confidence, FDI has flowed steadily into the financial intermediation, manufacturing, and real estate sectors of the Baltic economies with a significant share originating from Sweden, Finland, and Denmark. Given these shifts in economic linkages, an important question which arises concerns how the Baltic countries will respond to shocks from its major trading partners.

This paper analyses economic spillovers to the Baltic countries against the backdrop of their shifting trade patterns. We examine the relative effects of both external shocks in key trading partners as well as internal shocks captured by the real effective exchange rate on the Baltic economies. In particular, we would attempt to shed light on possible responses of the Baltic countries to shocks from their major trading partners given current trade linkages. In addition to identifying the magnitude of spillovers to each of these countries, this paper also

\footnotetext{
${ }^{2}$ Like much of the world, the current global crisis has had significant effects on the Baltic countries. However, work on this paper began well before the crisis fully materialized. The analyses only cover until end-2007, unless explicitly stated.
} 
measures the relative importance, and contribution of three potential sources of spillovers to the region, namely, trade linkages, financial channels, and commodity prices.

The rest of this paper is structured as follows. Section II discusses the 1998 Russian economic crisis and its effects on the Baltics. In section III, we present some stylized facts on trade and financial linkages of the Baltics with their major trading partners. Section IV uses vector autoregression (VAR) models to assess the dynamics, and severity of shocks in trading partners as well as to competitiveness in the Baltic economies. Following Bayoumi and Swiston (2007), we estimate the contribution of spillovers from trade, finance and commodity prices in section V while section VI concludes the paper with some policy implications.

\section{THE 1998 RUSSIAN CRISIS}

\section{The consequences of cross-border spillovers on the Baltics were particularly visible} during the Russian crisis (Figure 1). All three Baltic countries suffered precipitous declines in GDP growth rates during the crisis. Only Latvia did not fall into a recession during the period as both Estonia and Lithuania recorded negative growth rates from 1999Q1 to 1999Q3. The fall in growth seems to have been associated with reductions in the growth rates of investment and external demand. Investment fell more in Estonia and Latvia than in Lithuania. Lithuania's growth was mostly affected by the fall in total

The Baltics: Export exposure to Russia (in percent of GDP)

\begin{tabular}{cccc}
\hline & Estonia & Latvia & Lithuania \\
\hline $1994-99$ & 8.7 & 5.0 & 8.1 \\
$2000-04$ & 5.1 & 1.4 & 3.8 \\
2005 & 3.6 & 2.5 & 4.8 \\
2006 & 4.6 & 3.5 & 6.1 \\
2007 & 4.6 & 3.9 & 6.7 \\
\hline
\end{tabular}

Source: WEO Database and IMF staff calculations. exports given its relatively high export exposure to Russia. ${ }^{3}$ Remarkably, in all three Baltic countries, households appeared to smooth consumption, as consumption growth remained stable throughout the period.

\section{The recovery of Russia's output began in early 1999 and provided an impetus for} economic activity in the Baltics. This was initially driven by import substitution due to substantial real depreciation of the ruble, and had a further adverse effect on the Baltics. However, the recovery later became more broad based as domestic demand, including investment and private consumption, began to grow buoyantly. The Baltic countries responded to this rebound after two to three quarters with GDP growth rates turning positive by 2000Q1 in all the countries. Of the three Baltic countries, Latvia rebounded simultaneously in response to Russia's recovery while Estonia did so with a two-quarter lag. Lithuania's recovery was last and occurred with a three-quarter lag.

\footnotetext{
${ }^{3}$ Export exposure is calculated as the share of total exports to a given country as a percent of GDP.
} 
Figure 1. The Baltic Countries: Responses of Aggregate Demand Components to 1998 Russian Crisis (year-on-year change, in percent)
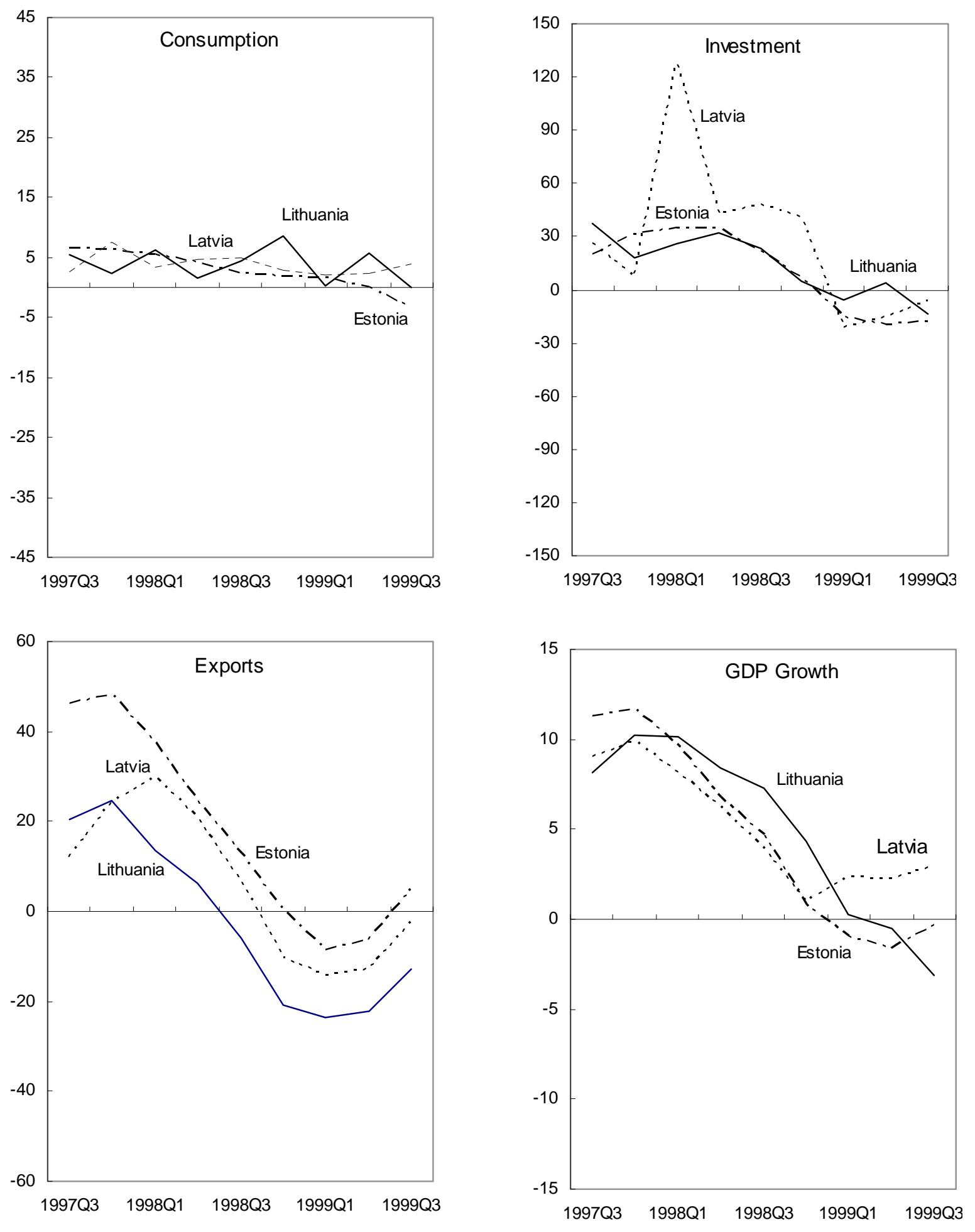

Source: Haver, Eurostat, and IMF staff calculations. 


\title{
III. Trade And Financial Linkages
}

\begin{abstract}
Russia and the European Union (EU) are the main trading partners of the Baltic countries (Figure 2). Except for Lithuania, more than 70 percent of imports to, and exports from the Baltic countries are directed towards the EU. Trade with advanced EU countries far outweighs trade with emerging EU countries especially in Estonia. Of the three Baltic countries, Lithuania imports the most from Russia. This high percentage of Lithuanian imports from Russia is mainly The Baltics: Trade with Other Baltic countries (in percent of total, 1994-07)

\begin{tabular}{lcc}
\hline & Exports & Imports \\
\hline Estonia & 13.5 & 8.4 \\
Latvia & 19.4 & 18.1 \\
Lithuania & 15.6 & 5.9 \\
\hline
\end{tabular}
due to imports of crude oil. Over the period 2005-07, fuels and lubricants accounted for about 75 percent of total imports and over 51 percent of total exports in Lithuania. Given their dominance of trade in the Baltics, Russia and the EU are key determinants of economic activity in the region. However, spillovers from these trading partners would not only affect one Baltic country directly but may also have significant indirect effects on the other Baltic countries because of high intra-regional trade. In terms of trade decomposition, trade in goods consistently outweighs trade in services in all three Baltic countries. ${ }^{4}$
\end{abstract}

\begin{tabular}{|c|c|c|c|}
\hline $\begin{array}{l}\text { Although Russia remains an importan } \\
\text { reorienting of Baltic exports toward th } \\
\text { countries before and after the Russian } \\
\text { crisis shows a significant decline in the }\end{array}$ & $\begin{array}{r}\text { The Balt } \\
\text { to Major T }\end{array}$ & $\begin{array}{l}\text { ies: Dire } \\
\text { artners (ii }\end{array}$ & $\begin{array}{l}\text { erable } \\
\text { ee Baltic } \\
\text { xports } \\
\text { t of total) }\end{array}$ \\
\hline share of exports to Russia and a & & $1994-99$ & $2000-07$ \\
\hline simultaneous increase in exports to the & & & \\
\hline EU. Specifically, exports to Russia has & Advanced EU & 51.2 & 58.5 \\
\hline fallen by nearly half over the two & Emerging EU & 13.8 & 14.4 \\
\hline $\begin{array}{l}\text { periods in each of the Baltic countries } \\
\text { with Latvian exports to Russia falling }\end{array}$ & Russia & 15.4 & 8.2 \\
\hline the most of all three Baltic countries. & Advanced EU & 39.4 & 51.0 \\
\hline Most of the increase in trade with & Emerging EU & 21.1 & 24.0 \\
\hline intra-regional trade in the Baltics. & Russia & 18.1 & 9.0 \\
\hline Similar trends also occurred in imports & & & \\
\hline with the share of Baltic country imports & Advanced EU & 37.2 & 41.2 \\
\hline from Russia having declined while those & Emerging EU & 19.5 & 24.2 \\
\hline of the EU increased over the same & Russia & 19.8 & 11.8 \\
\hline
\end{tabular}
period (see Table A1).

Source: IMF DTTS and IMF staff calculations.

\footnotetext{
${ }^{4}$ See Figure A1 for details.
} 
Figure 2. The Baltics: Exports and Imports of Goods and Services 1/ (in percent of total, 1994-2007)
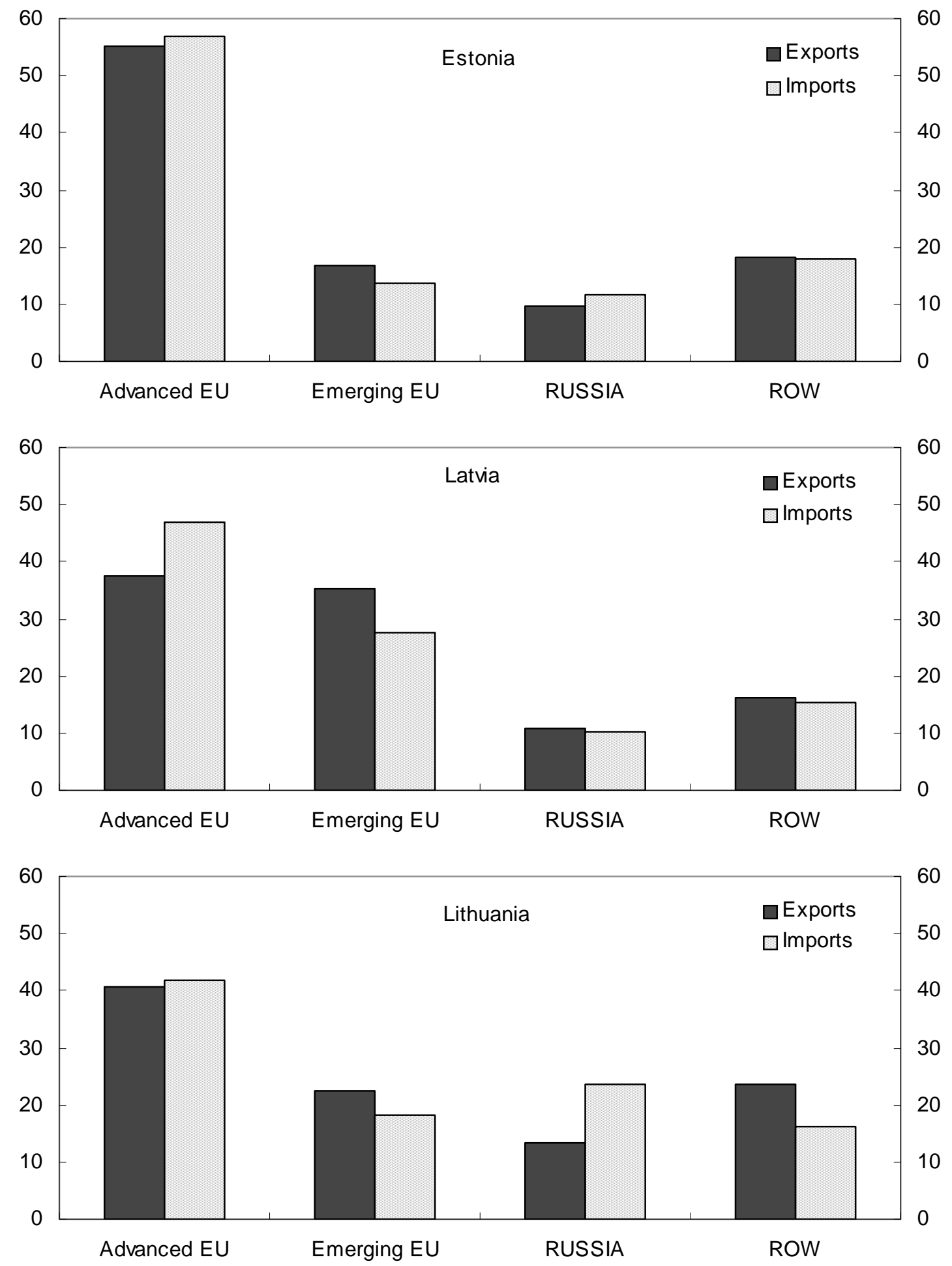

Source: IMF DTTS and IMF staff calculations.

1/ ROW stands for rest of the world 
Within the EU, Baltic trade is mostly concentrated in a small number of countries. Finland, Germany, Poland, Sweden, and the United Kingdom (UK) are the main trade partners of the Baltic countries in the EU. Except in Latvia, the top three EU trading partners have gained market shares in Baltic exports since the Russian crisis. Over the period 2000-07, they collectively account for over a third of exports from Estonia and Latvia and one-fifth of Lithuania's exports. Different kinds of goods dominate trade between individual Baltic countries and the EU. In Lithuania's case, plastics, furniture, wood and vehicles accounted for over a third of exports to Germany. Mineral fuels alone constituted

The Baltic Countries: Direction of Exports to top Three EU Trading Partners (in percent of total)

\begin{tabular}{lcc}
\hline & $1994-99$ & $2000-07$ \\
\hline Finland & \multicolumn{2}{c}{ (Estonia) } \\
Sweden & 16.4 & 21.9 \\
Germany & 14.4 & 13.3 \\
& 6.5 & 6.7 \\
Germany & \multicolumn{2}{c}{ (Latvia) } \\
UK & 14.4 & 11.4 \\
Sweden & 12.8 & 10.6 \\
& 8.9 & 8.4 \\
Germany & \multicolumn{2}{c}{ (Lithuania) } \\
UK & 13.2 & 10.2 \\
Poland & 3.5 & 6.2 \\
\hline
\end{tabular}

Source: IMF DTTS and IMF staff calculations.

over a third of her exports to Poland while more than 40 percent of its exports to the UK included clothing apparels, furniture, and mineral fuels.

\section{Economic ties with the $\mathrm{EU}$ have also intensified due to greater foreign direct investment} (FDI) from European countries. Especially since EU accession and the resultant increase in investors' confidence, foreign direct investment has flowed steadily into the Baltics (Table 1). Poland's dominance of FDI into Lithuania in 2007 reflects their partial purchase of Lithuania's oil refinery in 2006, with payments flowing into 2007. This also explains the share of FDI in the year which went to the country's manufacturing sector. Much of the EU funds have financed public investment and provided impetus for accompanying private investment.

Table 1. The Baltics: Sources and Destination of Foreign Direct Investment (in percent of total, 2007)

\begin{tabular}{lccc}
\hline Country & \% Share & Destination & \% Share \\
\hline Sweden & 39.3 & (Estonia) & \\
Finland & 24.9 & Real estate & 33.2 \\
Netherlands & 5.6 & Manufacturing & 26.8 \\
ROW & 30.2 & Others & 14.6 \\
& & (Latvia) & 25.4 \\
Estonia & 14.5 & Financial & 28.3 \\
Sweden & 13.9 & Real estate & 18.3 \\
Denmark & 8.9 & Manufacturing & 8.8 \\
ROW & 62.7 & Others & 44.7 \\
& \multicolumn{4}{c}{ (Lithuania) } \\
Poland & 18.0 & Manufacturing & 36.3 \\
Denmark & 12.9 & Financial & 17.2 \\
Sweden & 11.7 & Transport \& Comm. & 12.8 \\
ROW & 57.4 & Others & 33.7 \\
\hline
\end{tabular}

Sources: Baltic Central Banks and IMF staff calculations. 


\section{Linkages with the EU have also been reinforced by the dominance of foreign-owned} banks in the Baltics. In particular, a significant part of the bank ownership, measured by the share of banking sector assets, is owned by foreign banks. On average, over 80 percent of banking sector assets in the Baltics belongs to foreign-owned banks. This is mostly pronounced in Estonia where nearly 100 percent of the banking system is

The Baltics: Structure of Banking Sector Assets (in percent of total assets, Dec 2007)

\begin{tabular}{lccc}
\hline & Estonia & Latvia & Lithuania \\
\hline Foreign-owned banks & 97.1 & 56.0 & 91.7 \\
o/w: Hansabank & 52.0 & 22.0 & 23.9 \\
$\quad$ SEB & 22.6 & 15.0 & 30.4
\end{tabular}

Top 3 banks

$86.8 \quad 50.0 \quad 67.5$

Sources: Country Authorities and Author's Calculations. foreign-owned (see Table A2 for listing of banks and ownership). Two Swedish banks, Hansabank and SEB, are the two biggest banks in the region.

Financial linkages with major trading partners have been manifest in stock market developments. There is a fairly high correlation between the growth rate of stock price indices of the Baltic countries and those of their major trading partners. Specifically, the average correlation coefficient between the growth rate of stock price indices from the Baltic countries and those of their trading partner is $0.5,0.3$ and 0.4 for Estonia, Latvia and Lithuania, respectively. The Baltic stock market, with The Baltics: Correlation Coefficients with quarterly growth rates of trading partners' stock price indices (2000-07)

\begin{tabular}{cccc}
\hline & Estonia & Latvia & Lithuania \\
\hline GER & 0.49 & 0.23 & 0.40 \\
FIN & 0.54 & 0.42 & 0.44 \\
EU15 & 0.52 & 0.25 & 0.39 \\
RUS & 0.39 & 0.27 & 0.45 \\
SWE & 0.61 & 0.43 & 0.48 \\
EST & 1.00 & 0.39 & 0.68 \\
LAT & 0.39 & 1.00 & 0.48 \\
LTU & 0.68 & 0.48 & 1.00 \\
\hline
\end{tabular}

Source: Bloomberg and IMF staff calculations.

separate exchanges in Tallinn, Riga and Vilnius, is part of a worldwide exchange company, the NASDAQ OMX Group, which trades across Europe. This creates additional channels of spillovers to the Baltic countries from global occurrences in financial markets.

Given these linkages, the Baltic countries seem to have well synchronized business cycles with their major trading partners. Kose, et al (2003) argues that these similar cycles could reflect the influence of common world business cycles or common global shocks. Figure 3 shows there are fairly similar turning points in the business cycles of the Baltic countries and their key trading partners, with Baltic country cycles having become more synchronized with the EU since 2000. This might reflect the increase in trade over this period. As Coe and Helpman (1995) argue, the most obvious channel by which economic condition abroad influences a country's growth is through trade linkages. 
Figure 3. Baltic Countries: Business Cycle Synchronization with Major Trading Parners (1996-2007)
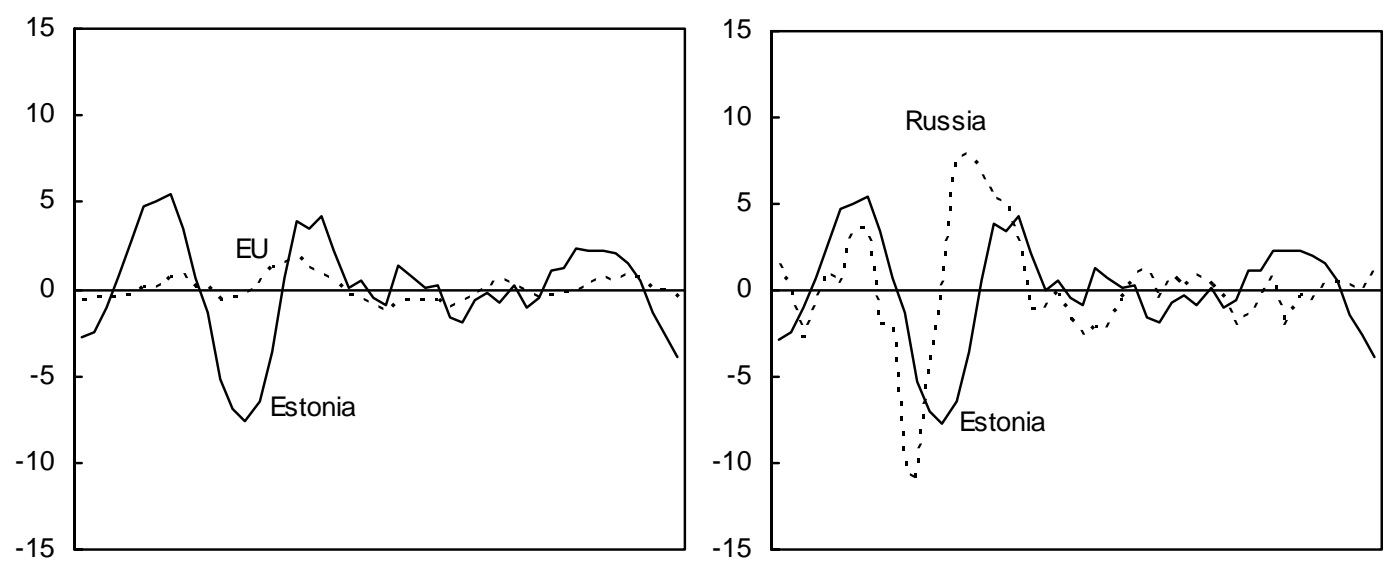

1996Q1 1998Q2 2000Q3 2002Q4 2005Q1 2007Q2 1996Q1 1998Q2 2000Q3 2002Q4 2005Q1 2007Q2
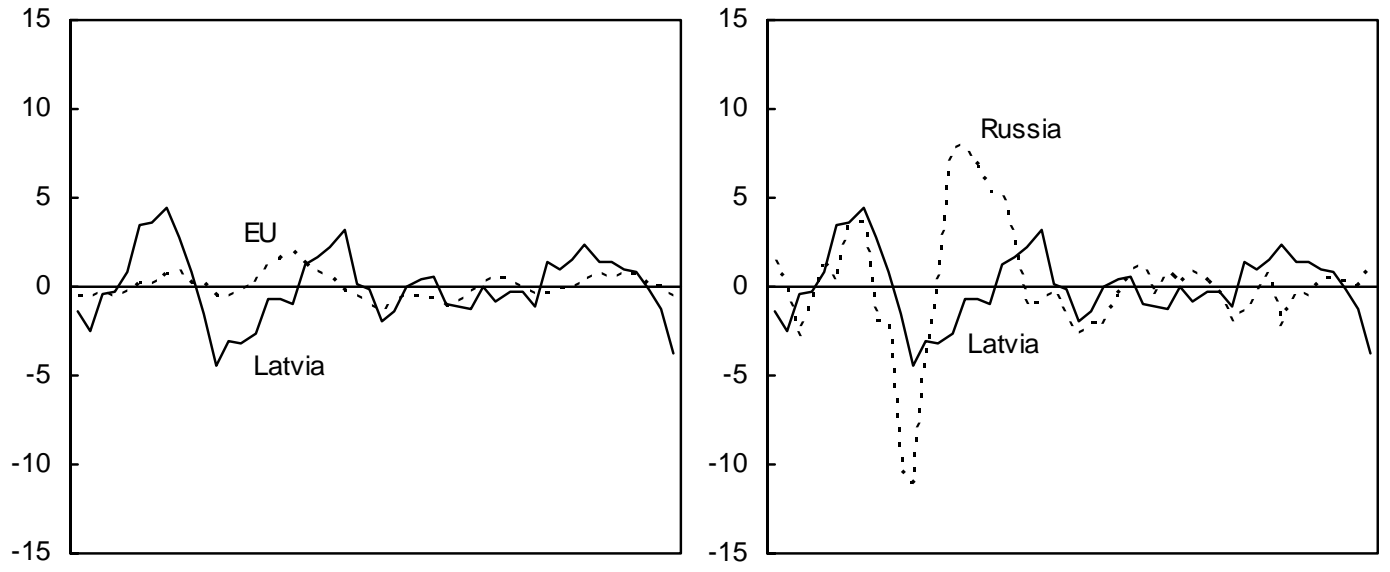

1996Q1 1998Q2 2000Q3 2002Q4 2005Q1 2007Q2

1996Q1 1998Q2 2000Q3 2002Q4 2005Q1 2007Q2

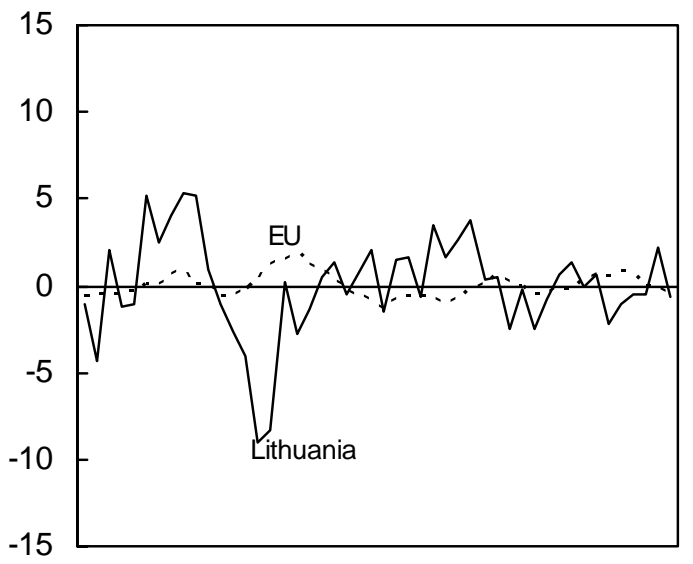

1996Q1 1998Q3 2001Q1 2003Q3 2006Q1

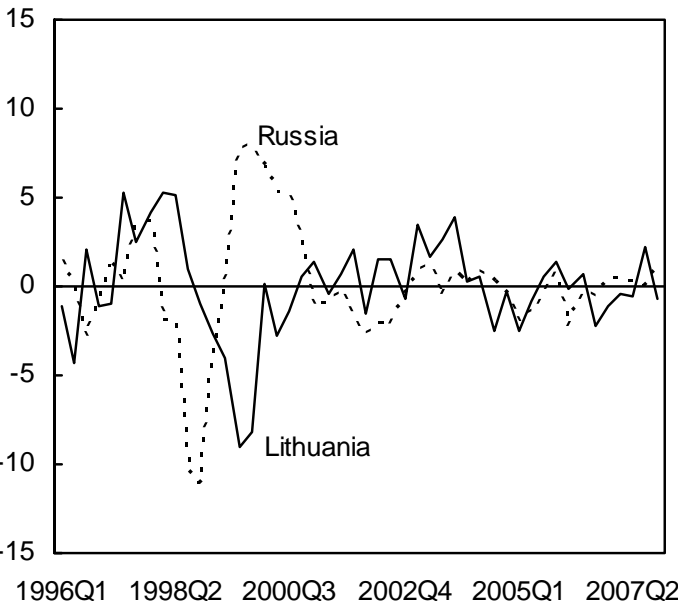

Source: Haver, Eurostat, and IMF staff calculations 


\section{ECONOMETRIC ANAlysis}

Having described the impact of the Russian crisis on the Baltics, this section turns to assessing their potential responses in the context of their current trading patterns. Given our understanding of the response of the Baltic countries to the erstwhile financial crisis in Russia, our goal in the econometric section will be to analyze what the effects might be in light of the trading patterns which have shifted from Russia toward the EU. Hence, data for the analyses spanned 2000:Q1 to 2007:Q4. This period is best suited to shed light on current responses of the Baltic countries to spillovers from their major trading partners given the rapid transformation of the Baltic countries over the past decade, and the perceived structural break in the data set from earlier periods.

\section{A combination of vector autoregression models were used to evaluate current growth} spillovers in the Baltic countries. In particular, a four-variable vector autoregression (VAR) model was estimated for each of the Baltic countries. Given the perceived effect of oil price growth in the Baltics vis-à-vis their economic linkages to Russia, these VAR models were extended to include the percentage change in oil prices. The analyses also decomposed the contributions of three potential channels of spillovers. All variables were seasonally adjusted and shown to be stationary using the Ng-Perron tests (see Table A3 for results). ${ }^{5}$

\section{A. Vector Autoregression Models}

Three vector autoregression (VAR) models were estimated to evaluate the impact of spillovers to the Baltic countries. The VAR models were estimated with four lags for each variable. ${ }^{6}$ Following Cholesky decomposition, the variables in the VAR were ordered as follows: EU real GDP growth, Russian real GDP growth, the Baltic country real GDP growth, and the unit labor cost (ULC) based real effective exchange rate (REER). In this regard, the ULC-based REER was preferred to the CPI-based REER because it better reflects a country's ability to sell its products in international markets and captures domestic cost considerations associated with tradable goods. For sensitivity analysis, the ordering of the EU real GDP and Russian real GDP were reversed and the results were not significantly sensitive to this change.

\footnotetext{
${ }^{5}$ This testing procedure was adopted because of its superiority in size and power over the more commonly-used Dickey-Fuller and Phillips-Perron tests. Especially in small samples, the Dickey-Fuller and Phillips-Perron tests tend to over-reject the null hypothesis when it is true and under-reject when it is false (see Dejong, et al, 1992 and Harris and Sollis, 2003 for details).

${ }^{6}$ Test results for Latvia and Lithuania pointed to two lags. However, we used four lags for each equation to allow for comparability. In addition to being the logical choice for quarterly data, this is also consistent with the specifications in Stock and Watson (2005), Perez, et al (2007) and Swiston and Bayoumi (2008).
} 
Variance decomposition results reveal that partner country shocks explain a substantial amount of variations in Estonian and Lithuanian GDP growth but much less so in Latvia (Table 2). Over a 12 quarter horizon, external shocks from Russia and the EU account for about 37 percent of variation in Estonian GDP growth, and over 46 percent in the case of Lithuania. In contrast, these shocks only account for 17 percent of variation in Latvian GDP. Shocks in EU GDP explain substantial variation in Estonian and Lithuanian GDP. In particular, about one-third of variation in their GDP is attributable to variation in EU GDP. With respect to Latvia, however, variation in EU GDP explains less than 12 percent of changes in its GDP. Furthermore, the share of variation attributable to EU GDP in the first three quarters is largest in Estonia. Over time, however, its share dissipates in Estonia but rises in Latvia and Lithuania.

The share of variation explained by Russian GDP is largest in Lithuania. Over a 12 quarter horizon, variation in Russian GDP explains about 15 percent of fluctuations in Lithuania’s GDP as against roughly 13 percent and 6 percent for Estonia and Latvia, respectively. This may be related to Lithuania's high export exposure to Russia, and the strategic influence of Russia on Lithuania's oil refinery. The share of variation attributable to Russia rises over time in all the Baltic countries. For Estonia and Latvia, it rises from $3 \frac{1}{2}$ percent and $2 \frac{1}{2}$ percent in the first quarter of the shock, to about 15 percent and 7 percent, respectively by the $12^{\text {th }}$ quarter. The size of Latvia's responsiveness to fluctuations in Russia's GDP seems to coincide with the discussion of the Russian crisis (section II) where only Latvia did not record negative growth as a result of the crisis.

Shocks to competitiveness explain a substantial share of output variation in Estonia and Latvia, particularly at longer horizons. On average, shocks to the REER accounts for nearly one-third of variation in Estonian and Latvian GDP growth. However, over the same period, only about 7 percent of variation in Lithuanian GDP growth is attributable to REER. Much of Lithuania's foreign trade is oil-related (see section B). Since oil is a tradable good whose prices are generally determined in the international oil market, changes in Lithuania's REER is not likely to cause significant changes in net exports and therefore, unlikely to account for a significant share of variation to the country's GDP growth. Similar to Estonia, Latvia's REER exerts considerable effects on Latvia's GDP over longer time horizons. Shocks to REER explain 41 percent of changes in Latvia's GDP in the $12^{\text {th }}$ quarter from only 3 percent in the first quarter. In all three cases, however, the share of variation in GDP growth attributable to changes in REER takes some time to build up. This implies that shocks to the REER may have much stronger effects on growth in the Baltic countries over longer time horizons. 
Table 2: Variance Decomposition for Baltic Countries' Real GDP (Base VAR Models)

\begin{tabular}{|c|c|c|c|c|}
\hline $\begin{array}{c}\text { Horizon } \\
\text { (Quarters) }\end{array}$ & EU15 GDP & Russia GDP & Estonia GDP & $\begin{array}{c}\text { REER } \\
\text { (ULC-based) }\end{array}$ \\
\hline 1 & 40.1 & 0.0 & 41.9 & 18.0 \\
\hline 2 & 34.0 & 4.7 & 29.7 & 31.7 \\
\hline 3 & 28.7 & 8.3 & 28.4 & 34.6 \\
\hline 4 & 24.4 & 7.5 & 30.7 & 37.4 \\
\hline 5 & 23.1 & 10.7 & 28.6 & 37.6 \\
\hline 6 & 24.5 & 11.8 & 27.6 & 36.1 \\
\hline 7 & 25.8 & 11.6 & 27.5 & 35.1 \\
\hline 8 & 26.0 & 11.0 & 30.0 & 33.1 \\
\hline 9 & 25.8 & 10.7 & 30.3 & 33.2 \\
\hline 10 & 25.7 & 11.1 & 30.1 & 33.1 \\
\hline 11 & 26.1 & 11.1 & 29.9 & 32.9 \\
\hline 12 & 26.9 & 11.2 & 30.1 & 31.8 \\
\hline $\begin{array}{c}\text { Horizon } \\
\text { (Quarters) }\end{array}$ & EU15 GDP & Russia GDP & Latvia GDP & $\begin{array}{c}\text { REER } \\
\text { (ULC-based) }\end{array}$ \\
\hline 1 & 4.8 & 0.2 & 90.0 & 5.0 \\
\hline 2 & 12.4 & 2.7 & 81.4 & 3.6 \\
\hline 3 & 11.2 & 4.8 & 70.7 & 13.3 \\
\hline 4 & 9.1 & 4.5 & 59.6 & 26.8 \\
\hline 5 & 7.9 & 3.9 & 52.0 & 36.1 \\
\hline 6 & 6.9 & 3.8 & 45.6 & 43.6 \\
\hline 7 & 6.5 & 3.7 & 44.8 & 45.0 \\
\hline 8 & 6.3 & 3.5 & 45.6 & 44.5 \\
\hline 9 & 6.2 & 3.7 & 46.5 & 43.7 \\
\hline 10 & 6.1 & 4.1 & 46.4 & 43.3 \\
\hline 11 & 6.3 & 4.5 & 46.1 & 43.1 \\
\hline 12 & 6.4 & 4.8 & 45.7 & 43.1 \\
\hline $\begin{array}{c}\text { Horizon } \\
\text { (Quarters) }\end{array}$ & EU15 GDP & Russia GDP & Lithuania GDP & $\begin{array}{c}\text { REER } \\
\text { (ULC-based) }\end{array}$ \\
\hline 1 & 9.9 & 12.7 & 75.5 & 1.9 \\
\hline 2 & 18.8 & 14.6 & 64.6 & 2.0 \\
\hline 3 & 26.3 & 18.1 & 53.5 & 2.0 \\
\hline 4 & 25.1 & 17.4 & 53.8 & 3.7 \\
\hline 5 & 32.4 & 15.4 & 47.4 & 4.8 \\
\hline 6 & 31.7 & 17.2 & 46.2 & 5.0 \\
\hline 7 & 31.2 & 19.3 & 44.5 & 5.1 \\
\hline 8 & 30.9 & 19.1 & 43.9 & 6.1 \\
\hline 9 & 31.9 & 18.7 & 43.4 & 6.0 \\
\hline 10 & 32.3 & 18.6 & 43.2 & 5.9 \\
\hline 11 & 32.1 & 18.7 & 43.3 & 5.9 \\
\hline 12 & 32.1 & 18.8 & 43.2 & 5.9 \\
\hline
\end{tabular}

Source: IMF staff calculations. 
Shocks to GDP of the Baltic countries explain a substantial share of variation to their GDP. Over the 12 quarter horizon, these shocks explain a third of fluctuations in Estonia and Lithuania and more than half of variation in Latvian GDP. Given these considerable effects, it implies that shocks to Baltic country GDP appear to propagate strongly within their economies. However, these effects tend to dissipate over time in all three countries. In particular, about 77 percent of variation in Latvian GDP during the first three quarters of the horizon is explained by changes in Latvian GDP itself but this effect reduces to about 42 percent in the $12^{\text {th }}$ quarter. In Lithuania, shocks to GDP explain about 61 percent of variation in the first three quarters but dissipates to 40 percent by the $12^{\text {th }}$ quarter of the shock.

The impulse response functions show that shocks from the EU exert significant effects on the growth rate of Baltic countries particularly in the first year (Figure 4). Impulse responses were normalized to one percent shocks to simplify comparison across countries. In all cases, there is a fairly significant contemporaneous increase in GDP growth rate for the Baltic country. A one percent shock from EU GDP growth rate boosts Estonia's GDP growth by about 2 percent for the first two quarters following the shock but decelerates gradually to - 1percent before recovering to nearly 1 percent in the $12^{\text {th }}$ quarter. The same shock from EU growth rate increases Latvia's GDP growth rate by $1 \frac{11 / 4}{4}$ percent in the second quarter but the effect dissipates to zero in the $5^{\text {th }}$ quarter. In the case of Lithuania, the results are somewhat confounding. One percent shock from EU growth rate leads to an immediate jump in Lithuania's GDP growth rate by $1 \frac{1}{2}$ percent but significantly depresses growth in Lithuania by about 2 percentage points in the third quarter before recovering by about $3 / 4$ percent in the tenth quarter. As expected, shocks from the EU exert the greatest effect on Estonia and least effect is on Latvia.

In contrast to EU shocks, the effects of shocks from Russian GDP are not large. In all the Baltic countries except Lithuania, shocks from Russian GDP simultaneously leave their GDP growth rate unaffected on impact. Lithuania’s GDP response to a one percent shock from Russia occurs contemporaneously with growth of about $1 / 2$ percent. Growth remains around this level until the fourth quarter when it decreases to about zero percent. The imprecision of Russia’s effects may be largely due to the fact that Russia exports oil. In particular, an increase in the international price of oil is likely to lead to a faster pace of economic activity in Russia while conversely having an adverse effect on the oil-importing Baltic countries. This is further discussed below. 
Figure 4. Baltic Countries: GDP Growth Responses to 1 Percent Shocks from Major Trading Partners and Real Effective Exchange Rate 1/
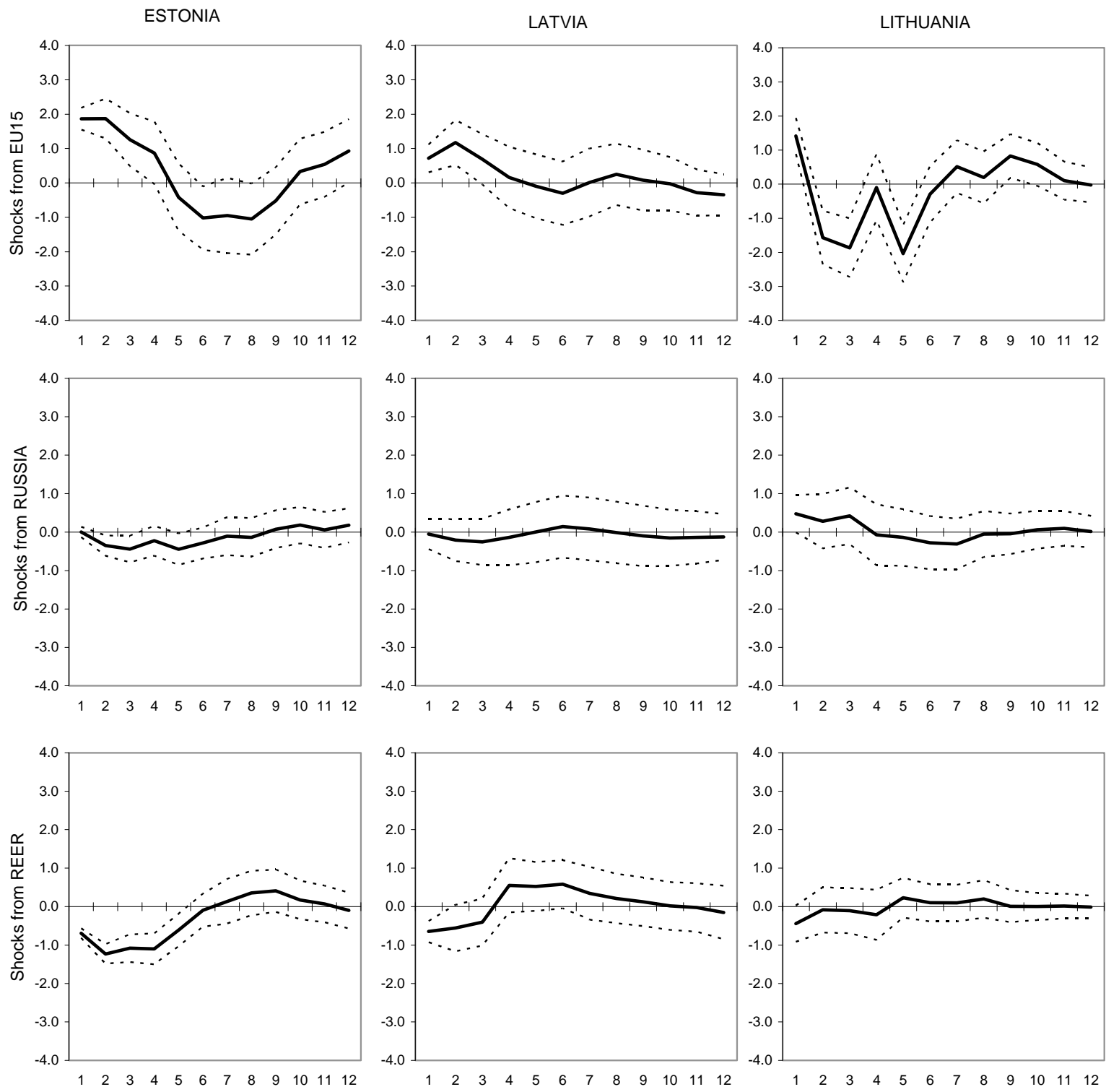

Source: IMF staff calculations

$1 /$ A shock to the real effective exchange rate corresponds to an appreciation 
An appreciation of the REER generally depresses growth in all three Baltic countries. In the context of increases in the REER signifying appreciation of the exchange rate, and therefore, a loss of international competitiveness, shocks to the REER have adverse effects on the Baltics, with the effects on Estonia and Latvia lasting much longer than in Lithuania. An increase in the REER contemporaneously depresses GDP growth in Estonia by about $3 / 4$ percent in the first quarter, deteriorates further to $1 \frac{11}{4}$ percent and continues up to the fifth quarter. In Latvia, an innovation to the REER contemporaneously reduces growth by about $1 / 2$ percent in the first quarter and lasts up to the fourth quarter. These results coincide with those from variance decomposition and strongly suggest that the effect of an appreciation of the REER could persist for over one year in these countries. Like those of the other Baltic countries, Lithuania's GDP growth also falls with an appreciation of the REER. However, the effects are is not statistically significant, and conform to the variance decomposition results.

\section{B. Extended Vector Autoregression Models}

To better assess Russia's effects, we introduced oil price growth to the VAR. Changes in the price of oil may have opposing effects on the Baltics because increases in oil prices may have positive effects on the Baltics through growth in Russia but may also impose negative supply shocks on them. The inclusion of oil price growth in the VAR, therefore, attempts to isolate the effects of Russia from those of oil prices. Results from the variance decomposition and impulse response functions are presented in Table 3 and Figure 4.

In terms of relative importance of shocks, growth in oil prices explains a significant share of variation in GDP growth for the Baltic countries. Over the $12^{\text {th }}$ quarter horizon, it accounts for an average of one-fifth of variation in Estonian and Latvian GDP growth and nearly one-third of variation in Lithuanian GDP growth. The inclusion of oil price growth in the base VAR also led to significantly higher share of variation in Baltic GDP growth attributable to Russia. In the base VAR, Russia accounted for an average of 9.1 percent, 33/4 percent, and 171/2 percent of fluctuations in GDP growth for Estonia, Latvia and Lithuania, respectively. With the inclusion of oil price growth, Russia's share of variation rises to 47 percent, 20 percent, and 181/2 percent for the three countries in the same order. 
Table 3: Variance Decomposition for Baltic Countries' Real GDP (Extended VAR Models)

\begin{tabular}{|c|c|c|c|c|c|}
\hline $\begin{array}{c}\text { Horizon } \\
\text { (Quarters) }\end{array}$ & $\begin{array}{l}\text { Oil Price } \\
\text { Growth }\end{array}$ & EU15 GDP & Russia GDP & Estonia GDP & $\begin{array}{c}\text { REER } \\
\text { (ULC-based) }\end{array}$ \\
\hline 1 & 25.4 & 41.3 & 17.2 & 13.8 & 2.3 \\
\hline 2 & 13.2 & 24.4 & 53.9 & 6.9 & 1.7 \\
\hline 3 & 10.2 & 15.0 & 66.3 & 3.6 & 4.8 \\
\hline 4 & 6.6 & 11.0 & 66.6 & 3.1 & 12.7 \\
\hline 5 & 13.9 & 6.8 & 56.9 & 3.5 & 19.0 \\
\hline 6 & 17.3 & 5.6 & 50.0 & 4.5 & 22.6 \\
\hline 7 & 22.8 & 5.4 & 44.8 & 4.3 & 22.6 \\
\hline 8 & 26.2 & 6.0 & 41.0 & 4.3 & 22.5 \\
\hline 9 & 26.0 & 7.1 & 40.3 & 4.2 & 22.3 \\
\hline 10 & 25.6 & 7.7 & 40.5 & 4.2 & 22.0 \\
\hline 11 & 24.8 & 8.3 & 41.0 & 4.3 & 21.7 \\
\hline 12 & 24.5 & 7.6 & 42.1 & 4.1 & 21.7 \\
\hline $\begin{array}{c}\text { Horizon } \\
\text { (Quarters) }\end{array}$ & $\begin{array}{l}\text { Oil Price } \\
\text { Growth }\end{array}$ & EU15 GDP & Russia GDP & Latvia GDP & $\begin{array}{c}\text { REER } \\
\text { (ULC-based) }\end{array}$ \\
\hline 1 & 20.5 & 0.8 & 2.9 & 66.1 & 9.5 \\
\hline 2 & 17.3 & 4.8 & 6.5 & 63.5 & 8.0 \\
\hline 3 & 13.9 & 6.5 & 17.3 & 51.7 & 10.6 \\
\hline 4 & 11.6 & 7.8 & 24.1 & 42.5 & 14.0 \\
\hline 5 & 11.1 & 9.0 & 26.4 & 36.7 & 16.8 \\
\hline 6 & 17.0 & 7.7 & 25.1 & 31.2 & 19.0 \\
\hline 7 & 19.3 & 7.1 & 23.6 & 29.8 & 20.2 \\
\hline 8 & 19.3 & 6.8 & 22.7 & 29.7 & 21.5 \\
\hline 9 & 18.9 & 7.0 & 22.6 & 29.5 & 22.1 \\
\hline 10 & 19.9 & 7.4 & 22.3 & 28.8 & 21.6 \\
\hline 11 & 21.9 & 7.1 & 21.5 & 28.0 & 21.5 \\
\hline 12 & 23.7 & 6.7 & 19.9 & 26.7 & 22.9 \\
\hline $\begin{array}{c}\text { Horizon } \\
\text { (Quarters) }\end{array}$ & $\begin{array}{l}\text { Oil Price } \\
\text { Growth }\end{array}$ & EU15 GDP & Russia GDP & Lithuania GDP & $\begin{array}{c}\text { REER } \\
\text { (ULC-based) }\end{array}$ \\
\hline 1 & 24.3 & 0.5 & 22.1 & 44.2 & 8.9 \\
\hline 2 & 20.2 & 16.6 & 18.5 & 36.9 & 7.8 \\
\hline 3 & 23.7 & 15.6 & 25.4 & 29.4 & 5.9 \\
\hline 4 & 22.9 & 15.8 & 24.7 & 30.6 & 5.9 \\
\hline 5 & 20.3 & 27.4 & 19.9 & 23.5 & 8.9 \\
\hline 6 & 20.5 & 27.2 & 19.9 & 23.5 & 8.9 \\
\hline 7 & 22.0 & 26.3 & 19.1 & 22.8 & 9.8 \\
\hline 8 & 25.9 & 24.5 & 17.0 & 20.6 & 12.0 \\
\hline 9 & 34.1 & 23.5 & 14.7 & 17.5 & 10.2 \\
\hline 10 & 44.3 & 20.1 & 12.1 & 14.9 & 8.7 \\
\hline 11 & 47.2 & 18.5 & 12.4 & 13.7 & 8.3 \\
\hline 12 & 45.4 & 19.2 & 14.5 & 13.1 & 7.8 \\
\hline
\end{tabular}

Source: IMF staff calculations. 
In contrast with the variance decomposition results of the base VAR model, the following emerge from the extended VAR model. First, the average share of variation to Baltic GDP attributable to EU GDP falls. Second, shocks from Russia GDP accounts for a significantly higher proportion of variation to GDP in the Baltic countries. This is especially noticeable in Latvia's case. In the extended model, however, shocks from Russia accounts for nearly 20 percent of variations in Latvian GDP compared to only 4 percent in the baseline model. Third, the share of variation attributable to REER falls in Estonia and Latvia but rises in the case of Lithuania. Finally, variation associated with changes from domestic GDP generally falls. One possible explanation to this result is that the share of variation associated with shocks from GDP in the base VAR models may also have been capturing supply side effects, most of which have now been accounted for by the inclusion of oil price growth in the extended VAR models.

Introducing oil price growth has the following effects on the impulse response functions (Figure 5). ${ }^{7}$ First, oil price shocks have negative effects in all three Baltic countries. The shock results in a contemporaneous decline in GDP growth rate by 0.2 percent, 0.3 percent and 0.5 percent in Estonia, Latvia, and Lithuania, respectively. Although the contemporaneous impact on Lithuania is the highest among the three countries, it makes the fastest recovery following the shock as its GDP growth rate rises by about half a percentage point in the second quarter and further by almost 1 percent in the fifth quarter. Second, the standard errors of the impulse response functions generally become smaller thereby suggesting an improvement in the precision of the estimates. Third, the responses from EU GDP growth remain largely unchanged while shocks from the REER depress growth in all three Baltic countries. Finally, the effects of shocks from Russia become significant. In particular, shocks from Russia have a negative effect on Estonia and Latvia but a positive effect on Lithuania.

Russia's negative effect on Estonia and Latvia could have several plausible explanations. Policies that seek to promote growth in one country by import substitution strategies which shift domestic demand from imports to locally produced goods may benefit that country at the expense of her trading partners. Such "beggar-thy-neighbor” policies may be implemented through higher tariffs, imposition of quotas, or competitive devaluations. A reduction in domestic inflation through currency appreciation may also improve the terms of trade of one country while worsening that of her trading partners. Furthermore, the existence of economies of agglomeration could also result in one country benefiting at the expense of another. Capital and investment may shift from one country to the nearest possible alternative in pursuit of better infrastructure and higher profitability. Higher commodity prices may also benefit exporting countries while hurting their trade partners.

\footnotetext{
${ }^{7}$ For robustness, we also estimated both VAR models using data from 1996:Q1 to 2007:Q4. The results (presented in Tables A4-A5 and Figures A2-A3) are not significantly different and strengthens our stance that the adopted sample (2000:Q1 to 2007:Q4) is best suited to shed light on current spillovers in the Baltics.
} 
Figure 5. Baltic Countries: GDP Growth Responses to 1 Percent Shocks from Major Trading Partners, Oil Price Growth and REER 1/
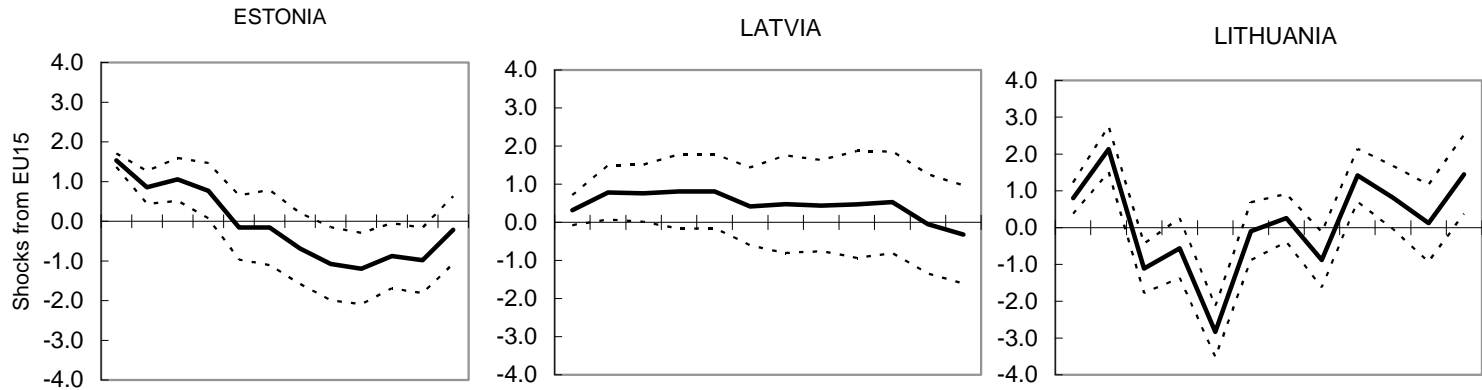

$\begin{array}{lllllllllllll}1 & 2 & 3 & 4 & 5 & 6 & 7 & 8 & 9 & 10 & 11 & 12\end{array}$

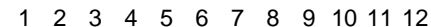

$\begin{array}{llllllllllll}1 & 2 & 3 & 4 & 5 & 6 & 7 & 8 & 9 & 10 & 11 & 12\end{array}$
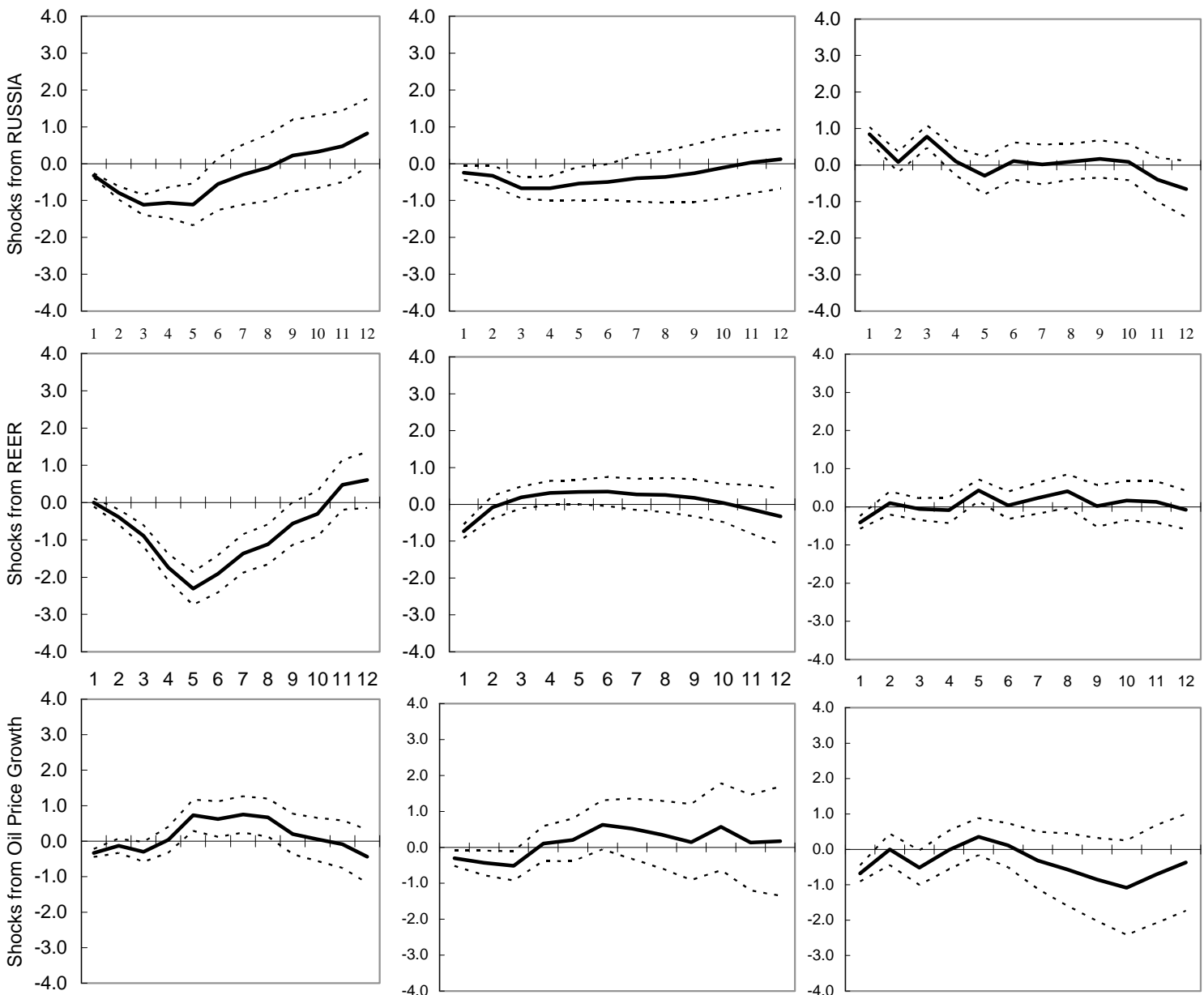

$\begin{array}{llllllllllll}1 & 2 & 3 & 4 & 5 & 6 & 7 & 8 & 9 & 10 & 11 & 12\end{array}$
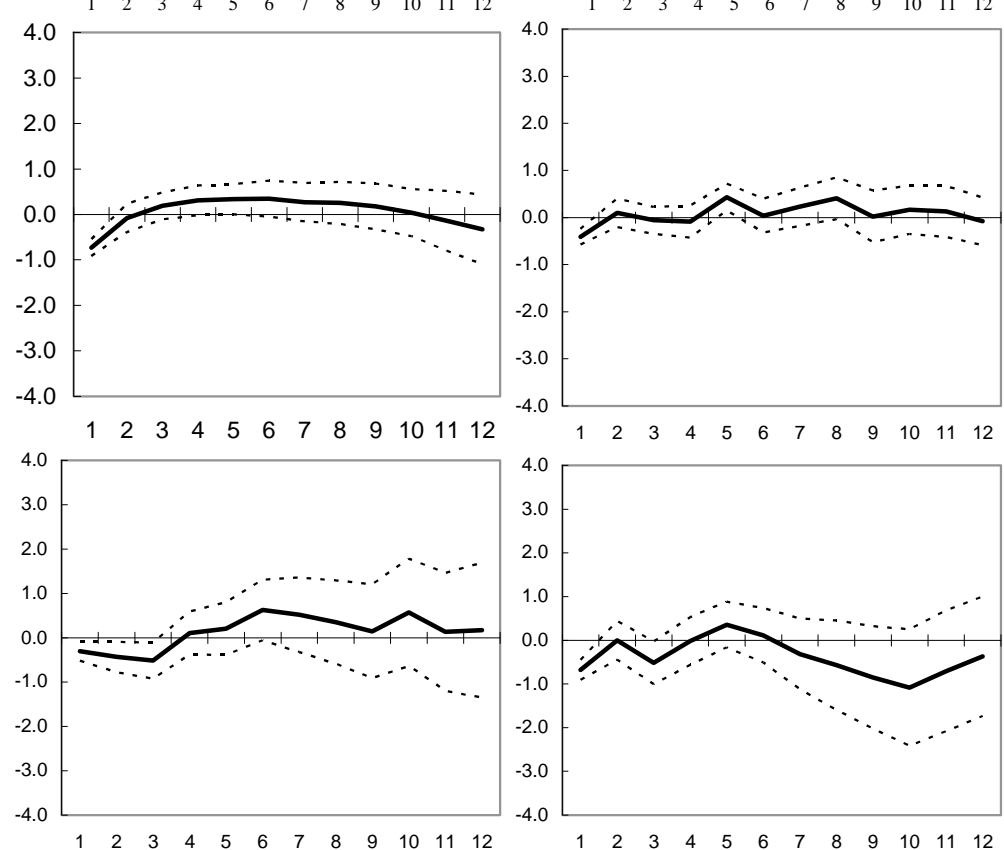

Source: IMF staff calculations.

$1 /$ A shock to the real effective exchange rate corresponds to an appreciation. 
In general, results from both the base and extended VAR models suggest that spillovers from the EU outweigh those from Russia. Variance decomposition results from both models suggest that the share of variation in GDP of the Baltic countries attributable to variation in EU GDP is significantly more than those attributable to variation in Russian GDP. More also, our impulse response functions show that the contemporaneous effects of shocks from the EU are higher than those from Russia. These results, which coincide with the findings of Shiells, et al (2005), might be related to the shift in trade towards Europe and the decline in export exposure of the Baltic countries to Russia.

\section{Measuring the Channels Of SPILlOVERS}

Following Bayoumi and Swiston (2007), we examine the relative importance of potential channels of spillovers to the Baltics. This procedure consists of augmenting our original VAR model by introducing variables that proxy for these potential channels of spillovers as exogenous variables in a separate VAR. The difference between the response of GDP in the base and augmented VAR is interpreted as the size of the spillover attributable to that particular channel. For example, the difference between the response of a Baltic country to Russia growth in the base VAR and the augmented VAR with financial conditions equals the impact of financial spillovers between the two countries. This difference is interpreted as the share of spillovers from Russia that is transmitted through financial linkages. Thus, the contribution of a given channel to spillovers can be given as:

$$
K_{i, j}=I R_{i}-I R_{i, j}
$$

where $K_{i, j}$ is the contribution of a particular channel to spillovers, $I R_{i}$ is the impulse responses from the base VAR while $I R_{i, j}$ is the responses from augmented VAR in which a given channel, $j$, is introduced as an exogenous variable, rather than as an additional equation in the VAR. Since the estimation of channels of spillovers are carried out using this separate methodology, the sum of the contributions is not constrained to reflect the estimates of total spillovers from the base VAR. Rather, our goal is to measure the relative importance and contribution of each potential source of spillovers.

The analysis considered three potential sources of spillovers, namely, trade, financial conditions, and commodity prices. Spillovers from trade were captured by the contribution of net exports to real GDP growth as it reflects the contemporaneous interaction of a given country with foreign demand, and is likely to be exogenous to domestic conditions. For financial channels, we used equity prices in EU countries. The non-energy component of the Goldman Sachs Commodity Index and the average petroleum spot price (APSP) of oil were used to capture commodity prices. These commodity prices were converted into real terms using the US GDP deflator because they are expressed in US dollars. To allow for transmission lags, both their contemporaneous and lagged values were introduced into the VAR in quarterly percent changes. 
In terms of spillovers from major trading partners, financial conditions and trade linkages are the most important channels of spillovers to Latvia and Lithuania (Figures 6 and 7). Jointly, these channels account for the transmission of over 75 percent of spillovers to Latvia and Lithuania, with Contribution to Overall Spillovers commodity prices contributing an average of 19 percent in Latvia and 25 percent in Lithuania. This result is quite plausible since the Baltic countries share contiguous borders with most of their major trading partners. In the case of financial channels, the result also conforms to a priori in the Baltic Countries (in percent).

\begin{tabular}{lccc}
\hline & Finance & Trade & Comm-prices \\
\hline EU15 & 23.4 & (Estonia) & \\
RUSSIA & 23.0 & 25.6 & 51.0 \\
& & 29.8 & 47.2 \\
EU15 & 36.8 & 41.7 & \\
RUSSIA & 26.4 & 58.1 & 21.4 \\
& & (Lithuania) & 15.5 \\
EU15 & 31.9 & 39.7 & 28.4 \\
RUSSIA & 37.5 & 41.3 & 21.2 \\
\hline
\end{tabular}
expectations given that over 80 percent of banking sector assets in the Baltics belongs to foreign-owned banks. Klyuev (2008) argues that financial conditions matter more than trade with regard to spillovers from the U.S. to Canada while Osterholm and Zettelmeyer (2007) finds that financial conditions are more important than commodity prices in transmitting spillovers from the U.S. to Mexico.

In Estonia, commodity prices account for the largest share of transmission of spillovers from major trading partners. On average, they account for nearly half of spillovers from the EU and Russia, with financial conditions and trade linkages contributing the remainder. The effect of commodity prices also seems to depend on the structure of trade in each country. As Bayoumi and Swiston (2007) argue, global commodity price shocks are likely to be dominated by oil prices. Therefore, their impact on GDP growth may be negative for net importers of commodities like Estonia.

\section{However, financial linkages are clearly the most dominant transmission channel of spillovers from the Scandinavian region (Figure 8). ${ }^{8}$ On average, financial conditions} account for the transmission of about 45 percent of spillovers from the Scandinavian region to the Baltics. This result coincides with the percentage of the country's banking system that is foreign-owned. In Estonia, nearly 100 percent of banks are foreign-owned, and specifically, 75 percent Contribution to Overall Spillovers in the Baltics from the Scandinanvian Region (in percent)

\begin{tabular}{lccc}
\hline & Finance & Trade & Comm-prices \\
\hline Estonia & 51.9 & 20.7 & 27.4 \\
Latvia & 40.1 & 31.6 & 28.3 \\
Lithuania & 42.6 & 29.4 & 28.0 \\
\hline
\end{tabular}
Source: IMF staff calculations. of banking sector assets belongs to only two Swedish banks. However, 56 percent and 92 percent of banks are foreign-owned in Latvia and Lithuania, respectively.

\footnotetext{
${ }^{8}$ The impulse response functions of the Baltics from a 1 percent shock from the region were similar to those from the EU. The results are presented in Figure A4.
} 
Figure 6. The Baltic Countries: Contributions to Spillovers from EU Countries
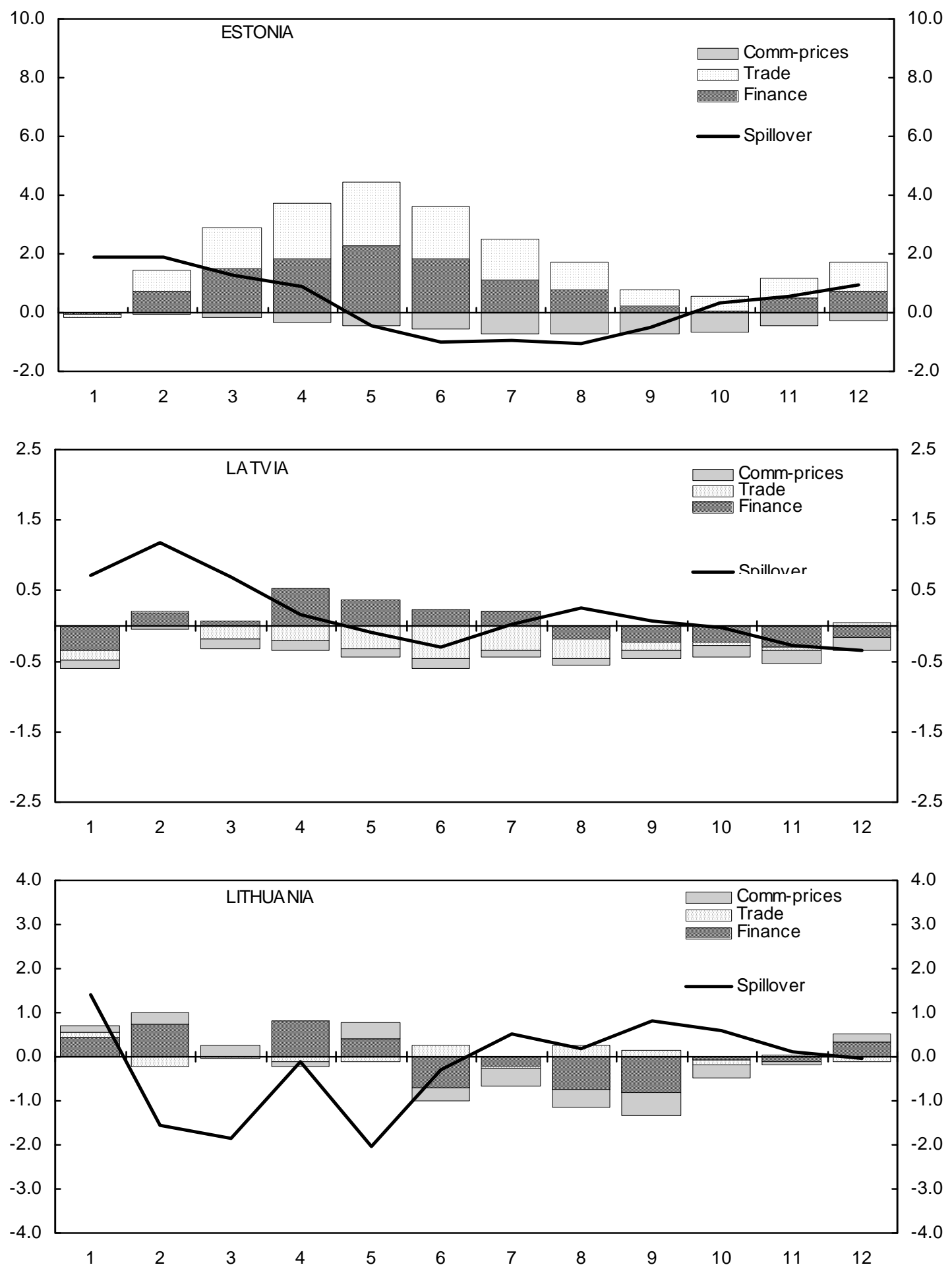

Source: IMF Staff Calculations. 
Figure 7. The Baltic Countries: Contribution to Spillovers from Russia
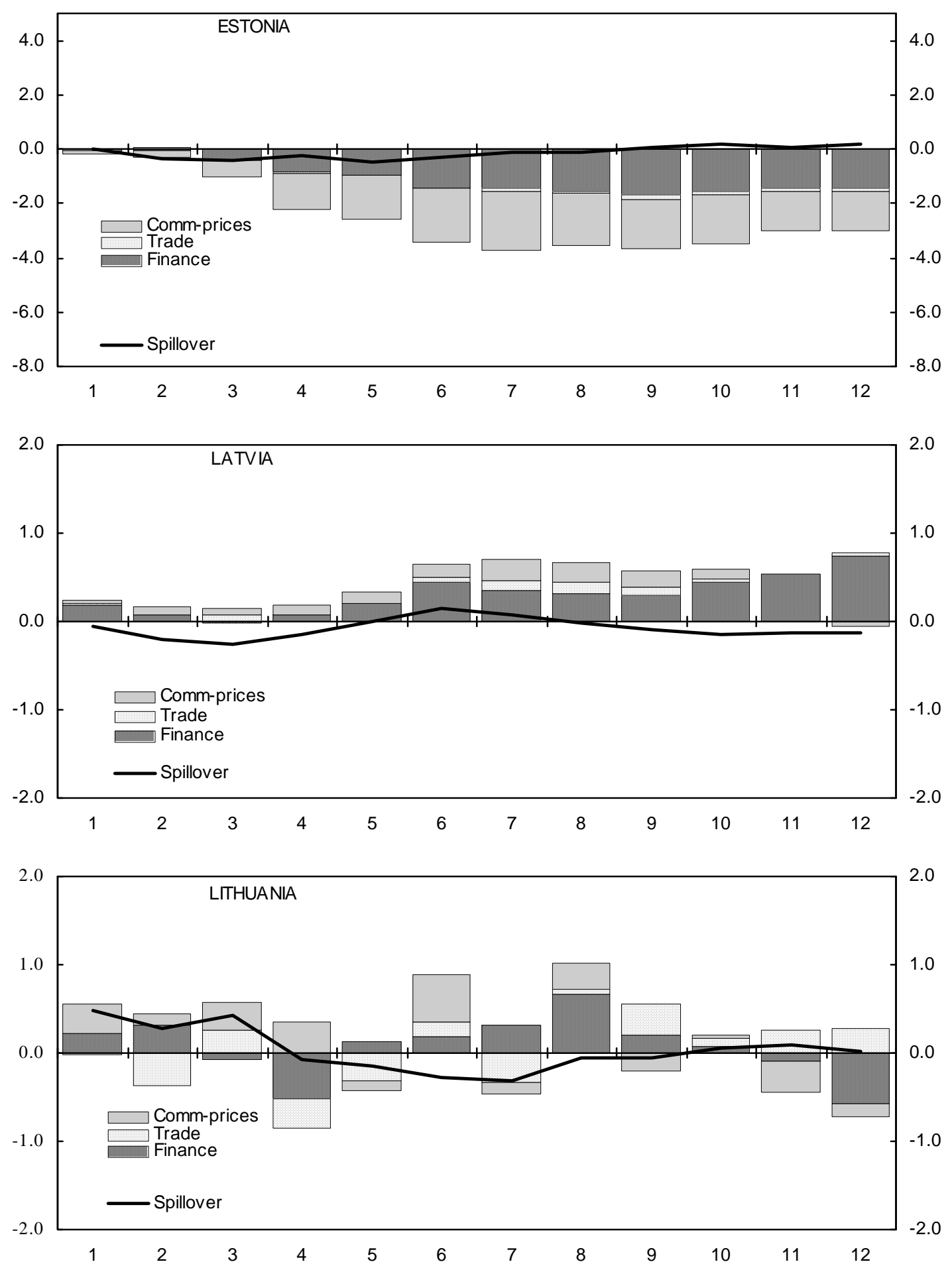

Source: IMF Staff Calculations. 
Figure 8. The Baltic Countries: Contributions to Spillovers from the Scandinavian Region
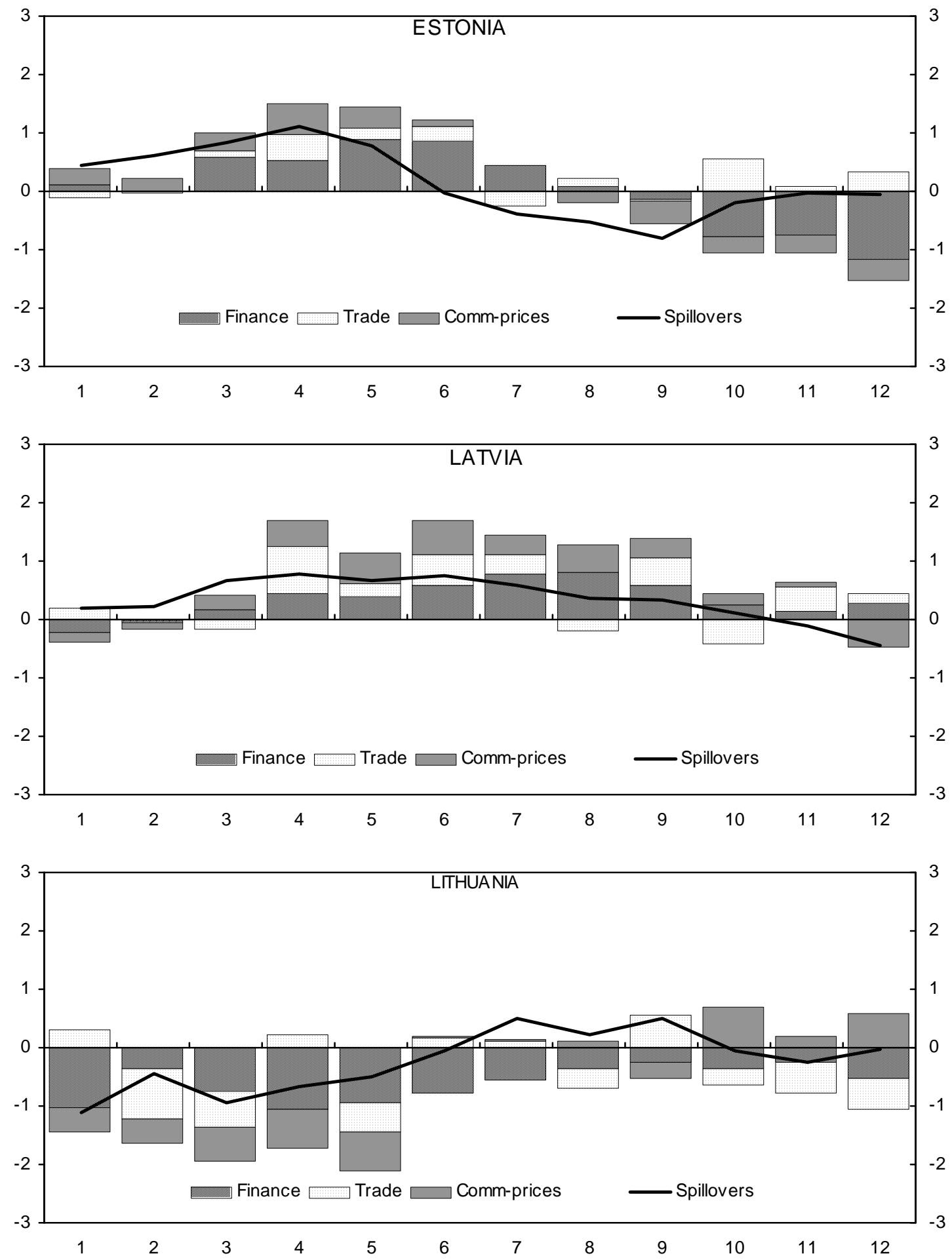

Source: IMF staff calculations. 


\section{Conclusions ANd Lessons for Policy}

This paper sought to examine growth spillovers to the Baltic countries in the context of shifting trade patterns. In addition to discussing trade and financial linkages between the Baltic countries and their major trading partners, vector autoregression (VAR) models were used to estimate the magnitude of spillovers from these partners and from shocks to the real effective exchange rate (REER). We have also evaluated the relative importance of potential channels of spillovers by decomposing our estimated spillovers into commodity prices, financial conditions and trade linkages.

The following conclusions emanate from our results. There are significant cross-country spillovers to the Baltic countries from their major trading partners, namely, the EU countries and Russia. However, both versions of our VAR models suggest that spillovers from the EU to the Baltics may be more than those from Russia, especially in the context of the changes in trade shares between the two major trade partners. Shocks from trading partners explain a significant share of variation in Estonian and Lithuanian GDP growth but less so for Latvia. While financial conditions and trade linkages are the most important transmission channels of spillovers in Latvia and Lithuania, commodity price channels transmit the largest share of spillovers to Estonia. The paper also shows that the effects of shocks from the Scandinavian region resemble those of the EU but financial linkages are the dominant channels of transmission of shocks from the region. Adverse shocks to the REER generally depress growth in the Baltics with its most significant effect on Estonia.

Several policy implications arise from these results. Against the backdrop of our finding that financial linkages and trade are important channels of spillovers to the Baltics, there are significant downside risks for growth in the Baltic countries following the global slowdown. In light of the significant effects of REER shocks on the Baltics, policy attention would be necessary to forestall a loss of competitiveness through rising wages, nominal appreciation, or high inflation. And given that our results suggest that REER shocks rise over time, changes in Baltic competitiveness may continue to impinge on growth farther than otherwise anticipated. 


\section{REFERENCES}

Arora, V. and A. Vamvakidis, 2006, "The Impact of U.S. Growth on the Rest of the World: How Much Does It Matter?” Journal of Economic Integration, Vol. 21, No. 1 (March), pp. 21-39

Bayoumi, T., and A. Swiston, 2007, "Foreign Entanglements: Estimating the Source and Size of Spillovers across Industrial Countries,” IMF Working Paper WP/07/182.

(Washington: International Monetary Fund).

Coe, D., E. Helpman, and A.W. Hoffmaister, 2008, “International R\&D Spillovers and Institutions,” NBER Working Paper No W14069

DeJong, D. N., J. C. Nankervis, N. E. Savin and C. H. Whiteman, 1992, “Integration Versus Trend Stationary in Time Series,” Econometrica, Vol. 60, No. 2, pp. 423-433

Harris, R., and R. Sollis, 2003, “Applied Time Series Modeling and Forecasting,” New York: John Wiley and Sons.

Herrero, A., and J. M. Ruiz, 2008, “Do Trade and Financial Linkages Foster Business Cycle Synchronization in a Small Economy?” Banco De Espana Working Paper No. 0810

Imbs, J., 2003, “Trade Finance, Specialization, and Synchronization,” IMF Working Paper 03/81 (Washington: International Monetary Fund).

Inklaar, R., R. Jong-A-Pin, and J. De Haan, 2005, “Trade and Business Cycle Synchronization in OECD Countries: A Re-Examination,” CESifo Working Paper Series No. 1546

International Monetary Fund, 2007, “Decoupling the Train? Spillovers and Cycles in the Global Economy” World Economic Outlook, (April), pp. 121-159

Kanda, D, 2007, “Spillovers to Ireland,” IMF Working Paper WP/08/2 (Washington: International Monetary Fund).

Klyuev, V., 2008, "Real Implications of Financial Linkages between Canada and the United States,” IMF Working Paper WP/08/23 (Washington: International Monetary Fund).

Koopman, S. J. and J. V. Azevedo, 2008, "Measuring Synchronization and Convergence of Business Cycles for the Euro area, UK and US," Oxford Bulletin of Economics and Statistics, Vol. 70, No. 1 pp. 23-51

Kose, M.A., C. Otrok, and C.H. Whiteman, 2003, "International Business Cycles: World, Region, and Country-Specific Factors,” American Economic Review, Vol. 93, No 4, pp. 1216-39. 
— E. Prasad, and M.E. Terrones, 2003a, "How Does Globalization Affect the Synchronization of Business Cycles,” IMF Working Paper 03/27 (Washington: International Monetary Fund).

Ng, S., and P. Perron, 1995, “Unit Root Tests in ARMA Models with Data-Dependent Methods for the Selection of the Truncation Lag," Journal of the American Statistical Association, Vol. 90, No 429, pp. 268-81.

— 2001, "Lag Length Selection and the Construction of Unit Root Tests with Good Size and Power,” Econometrica, Vol. 69, pp. 1519-54.

Österholm, P., and J. Zettelmeyer, 2007, “The Effect of External Conditions on Growth in Latin America,” IMF Working Paper WP/07/176.

Shiells, C. R., M. Pani, and E. Jafarov, 2005, “Is Russia Still Driving Regional Growth?” IMF Working Paper WP/05/192 (Washington: International Monetary Fund)

Stock, J. H., and M. W. Watson, 2003, “Understanding Changes in International Business Cycle Dynamics,” NBER Working Paper No.9859 (Cambridge, Massachusetts: National Bureau of Economic Research).

Swiston, A. and T. Bayoumi, 2008, "Spillovers Across NAFTA,” IMF Working Paper WP/08/3 (Washington: International Monetary Fund).

Zarnowitz, V., 1992, "Business cycles: Theory, history, indicators, and forecasting," (University of Chicago Press, Chicago) 


\section{Data Description}

EU real GDP. Quarterly GDP for the EU-15 countries in millions of euros at 1995 prices. Source: Eurostat.

Russia real GDP. Quarterly GDP in billions of rubles at average 2003 prices. Pre-2003 and post-2003 GDP are derived using y-o-y changes based on chain-linked method. Source: Federal State Statistics Service and IMF staff calculation.

Estonia real GDP. Quarterly GDP in billions of national currency at 1995 prices. Source: World Economic Outlook (WEO) Database.

Latvia real GDP. Quarterly GDP in billions of national currency at 1995 prices. Source: World Economic Outlook (WEO) Database.

Lithuania real GDP. Quarterly GDP in billions of national currency at 1995 prices. Source: World Economic Outlook (WEO) Database.

Scandinavia real GDP. Aggregate of purchasing power parity (PPP) weighted GDP for Denmark and Sweden. Source: World Economic Outlook (WEO) Database.

Commodity prices. Average petroleum spot price (APSP) of oil and the non-Energy component of the Goldman Sachs Commodities Index.

Contribution of net exports to GDP. Computed from trade and GDP data from country authorities.

REER. Real effective exchange rate for each Baltic country based on economy-wide unit labor cost (ULC). Source: Eurostat. 
Table A1. The Baltic Countries: Direction of Imports to Major Trading Partners (in percent of total)

\begin{tabular}{lccc}
\hline & $1994-99$ & $2000-07$ \\
\hline Advanced EU & 52.6 & & 56.3 \\
Emerging EU & 9.4 & & 15.2 \\
Russia & 13.7 & & 11.0 \\
& & (Latvia) & \\
Advanced EU & 50.4 & & 51.9 \\
Emerging EU & 18.8 & & 20.4 \\
Russia & 16.0 & 8.7 \\
& & (Lithuania) & \\
Advanced EU & 46.7 & & 51.3 \\
Emerging EU & 9.1 & & 10.0 \\
Russia & 25.6 & 23.0 \\
\hline Source:
\end{tabular}

Source: IMF DTTS and IMF staff calculations. 
Table A2. Structure of Bank Ownership in the Baltic Countries

\begin{tabular}{ccc}
\hline ESTONIA & LATVIA & LITHUANIA \\
\hline Foreign Banks & Foreign Banks & Foreign Banks \\
AS Eesti Krediidipank & SEB(AB Sweden) & AS UniCredit Bank \\
AS Hansabank & UniCredit Bank & MP Investment Bank \\
AS SEB Bank & DnB NORD Bank & Balti Investeeringute Grupi Bank \\
Balti Investeeringute Grupi Bank & HANSABANK & Allied Irish Bank \\
Marfin Pank Eesti AS & AS Bank Snoras & Danske Bank \\
Tallinna Äripanga AS & Latvijas tirdzniecības bank & Nordea Bank \\
Foreign Branches & JSCB Bank of Moscow & AB DnB NORD Bank \\
AB Bank Snoras & PrivatBank & AB SEB Bank \\
AS Parex Bank & SMP Bank & AB PAREX Bank \\
AS UniCredit Bank & AB Pivdenny & AB bankas Hansabank \\
Allied Irish Bank & & \\
Bank DnB NORD & Foreign Branches & Local Banks \\
Danske Bank & Nordea Bank & AB Ükio Bank \\
Nordea Bank & Svenska Handelsbanken & AB bankas FINASTA \\
Svenska Handelsbanken & Allied Irish Bank & AB Šiaulių Bank \\
Scania Finaas Bank & Danske Bank & AB Bank Snoras \\
Siemens Financial Services Bank & & UAB Medicinos Bank
\end{tabular}


Table A3. Results of Unit Root Tests Using the Ng-Perron Procedure Test statistics $1 /$ Critical values

\begin{tabular}{|c|c|c|c|c|}
\hline & & 1 Percent level & 5 Percent level & 10 percent level \\
\hline \multicolumn{5}{|c|}{ Estonia Real GDP } \\
\hline $\mathrm{MZa}$ & $-20.07^{\star \star \star}$ & -13.80 & -8.10 & -5.70 \\
\hline $\mathrm{MZt}$ & $-3.17^{\star \star \star}$ & -2.58 & -1.98 & -1.62 \\
\hline MSB & $0.16^{\star \star \star}$ & 0.17 & 0.23 & 0.28 \\
\hline MPT & $1.23^{\star \star \star}$ & 1.78 & 3.17 & 4.45 \\
\hline \multicolumn{5}{|c|}{ Latvia Real GDP } \\
\hline $\mathrm{MZa}$ & $-70.67^{\star \star *}$ & -13.80 & -8.10 & -5.70 \\
\hline $\mathrm{MZt}$ & 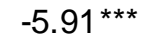 & -2.58 & -1.98 & -1.62 \\
\hline MSB & $0.08^{\star \star \star}$ & 0.17 & 0.23 & 0.28 \\
\hline MPT & $1.46^{\star \star \star}$ & 1.78 & 3.17 & 4.45 \\
\hline \multicolumn{5}{|c|}{ Lithuania Real GDP } \\
\hline $\mathrm{MZa}$ & $-13.26^{\star \star \star}$ & -13.80 & -8.10 & -5.70 \\
\hline $\mathrm{MZt}$ & $-2.56^{\star \star \star}$ & -2.58 & -1.98 & -1.62 \\
\hline MSB & $0.19 * \star \star$ & 0.17 & 0.23 & 0.28 \\
\hline MPT & $1.91^{\star \star \star}$ & 1.78 & 3.17 & 4.45 \\
\hline \multicolumn{5}{|c|}{ EU15 Real GDP } \\
\hline $\mathrm{MZa}$ & $-11.12^{\star \star *}$ & -13.80 & -8.10 & -5.70 \\
\hline $\mathrm{MZt}$ & $-2.35^{\star \star \star}$ & -2.58 & -1.98 & -1.62 \\
\hline MSB & $0.21^{\star \star \star}$ & 0.17 & 0.23 & 0.28 \\
\hline MPT & $2.22^{\star * *}$ & 1.78 & 3.17 & 4.45 \\
\hline \multicolumn{5}{|c|}{ Russia Real GDP } \\
\hline $\mathrm{MZa}$ & $-44.81^{\star \star \star}$ & -13.80 & -8.10 & -5.70 \\
\hline $\mathrm{MZt}$ & $-4.73^{\star \star \star}$ & -2.58 & -1.98 & -1.62 \\
\hline MSB & $0.11^{\star \star \star}$ & 0.17 & 0.23 & 0.28 \\
\hline MPT & $2.04^{\star * \star}$ & 1.78 & 3.17 & 4.45 \\
\hline \multicolumn{5}{|c|}{ Estonia REER } \\
\hline $\mathrm{MZa}$ & $-15.71^{\star \star \star}$ & -13.80 & -8.10 & -5.70 \\
\hline $\mathrm{MZt}$ & $-2.72^{\star \star \star}$ & -2.58 & -1.98 & -1.62 \\
\hline MSB & $0.17^{\star \star \star}$ & 0.17 & 0.23 & 0.28 \\
\hline MPT & $6.27^{\star \star \star}$ & 1.78 & 3.17 & 4.45 \\
\hline \multicolumn{5}{|c|}{ Latvia REER } \\
\hline $\mathrm{MZa}$ & $-26.23^{\star \star \star}$ & -13.80 & -8.10 & -5.70 \\
\hline MZt & $-3.55^{\star \star \star}$ & -2.58 & -1.98 & -1.62 \\
\hline MSB & $0.14^{\star \star \star}$ & 0.17 & 0.23 & 0.28 \\
\hline MPT & $3.92^{\star}$ & 1.78 & 3.17 & 4.45 \\
\hline \multicolumn{5}{|c|}{ Lithuania REER } \\
\hline $\mathrm{MZa}$ & $-31.62^{\star \star \star}$ & -13.80 & -8.10 & -5.70 \\
\hline $\mathrm{MZt}$ & $-3.97^{\star \star \star}$ & -2.58 & -1.98 & -1.62 \\
\hline MSB & $0.13^{\star \star \star}$ & 0.17 & 0.23 & 0.28 \\
\hline MPT & $2.90^{\star \star}$ & 1.78 & 3.17 & 4.45 \\
\hline
\end{tabular}

Source. IMF staff calculations.

$1 /{ }^{*},{ }^{*}$, and ${ }^{* * *}$ represent rejection of the unit root hypothesis at the 10 percent, 5 percent, and 1 percent levels, respectively. 
Table A4. Variance Decomposition Results

(Base VAR Models, 1996-2007)

\begin{tabular}{ccccc} 
Horizon & EU15 GDP & Russia GDP & Estonia GDP & REER \\
\hline (Quarters) & & & & (ULC-based) \\
\hline 1 & 18.2 & 3.6 & 78.2 & 0.0 \\
2 & 9.6 & 3.9 & 76.8 & 9.7 \\
3 & 6.3 & 4.1 & 79.9 & 9.8 \\
4 & 7.3 & 2.8 & 83.2 & 6.7 \\
5 & 16.1 & 2.3 & 76.1 & 5.5 \\
6 & 25.2 & 2.0 & 67.0 & 5.8 \\
7 & 33.7 & 1.8 & 57.4 & 7.1 \\
8 & 36.2 & 1.9 & 54.3 & 7.6 \\
9 & 33.5 & 3.0 & 54.7 & 8.8 \\
10 & 30.3 & 4.9 & 56.0 & 8.8 \\
11 & 28.4 & 6.7 & 56.5 & 8.4 \\
12 & 28.6 & 8.4 & 54.9 & 8.2
\end{tabular}

\begin{tabular}{ccccc}
\hline $\begin{array}{c}\text { Horizon } \\
\text { (Quarters) }\end{array}$ & EU15 GDP & Russia GDP & Latvia GDP & $\begin{array}{c}\text { REER } \\
\text { (ULC-based) }\end{array}$ \\
\hline 1 & 2.4 & 3.3 & 94.4 & 0.0 \\
2 & 4.9 & 6.4 & 88.0 & 0.8 \\
3 & 4.6 & 4.9 & 74.6 & 15.9 \\
4 & 4.7 & 4.8 & 57.6 & 32.9 \\
5 & 6.5 & 4.5 & 41.5 & 47.5 \\
6 & 8.2 & 4.4 & 31.1 & 56.3 \\
7 & 10.6 & 4.8 & 26.7 & 57.9 \\
8 & 12.1 & 5.0 & 25.0 & 57.9 \\
9 & 13.7 & 5.6 & 23.5 & 57.2 \\
10 & 14.9 & 6.1 & 22.8 & 56.2 \\
11 & 15.6 & 6.5 & 22.2 & 55.6 \\
12 & 16.3 & 6.9 & 21.6 & 55.2 \\
& & & & \\
\hline Horizon & EU15 GDP & Russia GDP & Lithuania GDP & REER \\
(Quarters) & & & & (ULC-based) \\
\hline 1 & 1.9 & 0.1 & 98.0 & 0.0 \\
2 & 1.6 & 0.8 & 95.6 & 2.0 \\
3 & 3.9 & 1.9 & 92.4 & 1.8 \\
4 & 3.2 & 2.1 & 87.1 & 7.6 \\
5 & 4.3 & 3.6 & 84.0 & 8.1 \\
6 & 7.8 & 4.2 & 79.9 & 8.1 \\
7 & 10.8 & 4.6 & 76.6 & 8.0 \\
8 & 16.4 & 4.4 & 72.0 & 7.2 \\
9 & 20.2 & 4.1 & 68.8 & 6.9 \\
10 & 22.2 & 4.0 & 67.1 & 6.7 \\
11 & 23.3 & 4.0 & 65.9 & 6.7 \\
12 & 23.5 & 4.2 & 65.4 & 6.9 \\
\hline
\end{tabular}

Source: IMF staff calculations. 
Table A5. Variance Decomposition Results (Extended VAR Models, 1996-2007)

\begin{tabular}{|c|c|c|c|c|c|}
\hline Horizon & Oil Price & EU15 GDP & Russia GDP & Estonia GDP & REER \\
\hline (Quarters) & Growth & & & & (ULC-based) \\
\hline 1 & 0.0 & 29.4 & 9.0 & 61.6 & 0.0 \\
\hline 2 & 8.6 & 15.7 & 7.7 & 60.4 & 7.6 \\
\hline 3 & 7.7 & 12.5 & 7.0 & 63.5 & 9.3 \\
\hline 4 & 10.7 & 10.1 & 5.3 & 66.4 & 7.4 \\
\hline 5 & 18.7 & 13.2 & 4.7 & 57.1 & 6.3 \\
\hline 6 & 20.2 & 19.5 & 4.1 & 50.2 & 6.0 \\
\hline 7 & 18.8 & 28.1 & 3.5 & 43.5 & 6.1 \\
\hline 8 & 17.2 & 33.3 & 3.2 & 40.7 & 5.7 \\
\hline 9 & 17.3 & 33.5 & 3.8 & 39.5 & 5.8 \\
\hline 10 & 18.9 & 31.8 & 5.0 & 38.0 & 6.3 \\
\hline 11 & 20.2 & 30.1 & 7.0 & 35.9 & 6.9 \\
\hline 12 & 20.4 & 28.8 & 9.4 & 32.5 & 8.8 \\
\hline $\begin{array}{c}\text { Horizon } \\
\text { (Quarters) }\end{array}$ & $\begin{array}{l}\text { Oil Price } \\
\text { Growth }\end{array}$ & EU15 GDP & Russia GDP & Latvia GDP & $\begin{array}{c}\text { REER } \\
\text { (ULC-based) }\end{array}$ \\
\hline 1 & 12.7 & 0.2 & 0.6 & 86.5 & 0.0 \\
\hline 2 & 11.4 & 1.8 & 3.3 & 83.3 & 0.2 \\
\hline 3 & 14.2 & 2.3 & 2.8 & 76.7 & 4.0 \\
\hline 4 & 20.9 & 3.1 & 2.3 & 67.0 & 6.8 \\
\hline 5 & 26.4 & 4.4 & 1.8 & 54.7 & 12.7 \\
\hline 6 & 34.0 & 4.5 & 1.4 & 40.9 & 19.2 \\
\hline 7 & 36.0 & 4.0 & 2.9 & 32.3 & 24.8 \\
\hline 8 & 32.3 & 3.2 & 6.1 & 26.3 & 32.1 \\
\hline 9 & 28.0 & 2.7 & 10.3 & 22.0 & 37.0 \\
\hline 10 & 24.5 & 2.4 & 14.1 & 19.3 & 39.6 \\
\hline 11 & 22.7 & 2.3 & 16.4 & 17.9 & 40.9 \\
\hline 12 & 21.8 & 2.2 & 17.5 & 17.2 & 41.3 \\
\hline $\begin{array}{c}\text { Horizon } \\
\text { (Quarters) }\end{array}$ & $\begin{array}{l}\text { Oil Price } \\
\text { Growth }\end{array}$ & EU15 GDP & Russia GDP & Lithuania GDP & $\begin{array}{c}\text { REER } \\
\text { (ULC-based) }\end{array}$ \\
\hline 1 & 0.0 & 0.0 & 0.1 & 99.9 & 0.0 \\
\hline 2 & 12.5 & 1.4 & 4.9 & 80.8 & 0.4 \\
\hline 3 & 15.8 & 6.9 & 4.4 & 71.6 & 1.3 \\
\hline 4 & 14.7 & 6.3 & 4.2 & 69.1 & 5.6 \\
\hline 5 & 14.4 & 7.8 & 4.7 & 67.3 & 5.8 \\
\hline 6 & 14.9 & 5.2 & 10.6 & 63.9 & 5.4 \\
\hline 7 & 16.8 & 8.5 & 11.7 & 58.1 & 5.0 \\
\hline 8 & 18.4 & 14.6 & 10.7 & 51.6 & 4.6 \\
\hline 9 & 20.5 & 16.0 & 13.6 & 45.8 & 4.2 \\
\hline 10 & 20.0 & 16.0 & 17.1 & 42.5 & 4.5 \\
\hline 11 & 19.1 & 16.4 & 18.8 & 40.7 & 5.0 \\
\hline 12 & 18.8 & 16.1 & 20.1 & 39.8 & 5.2 \\
\hline
\end{tabular}

Source: IMF staff calculations. 
Figure A1. The Baltic Countries: Decomposition of Exports and Imports (in percent of GDP, 1993-2007)
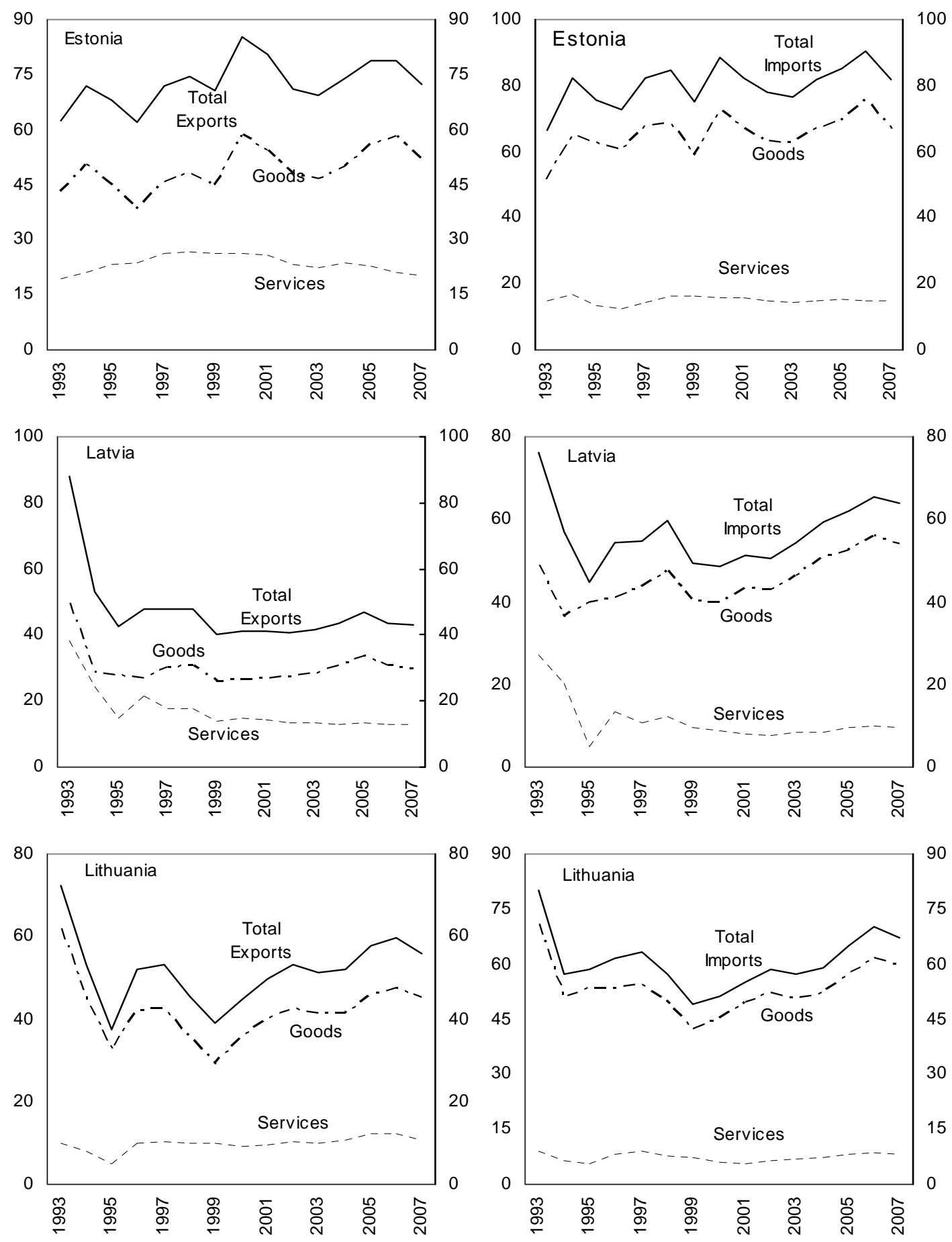

Source: WEO Database and Author's Calculation. 
Figure A2. Impulse Response Results

(Base VAR Models, 1996-2007)
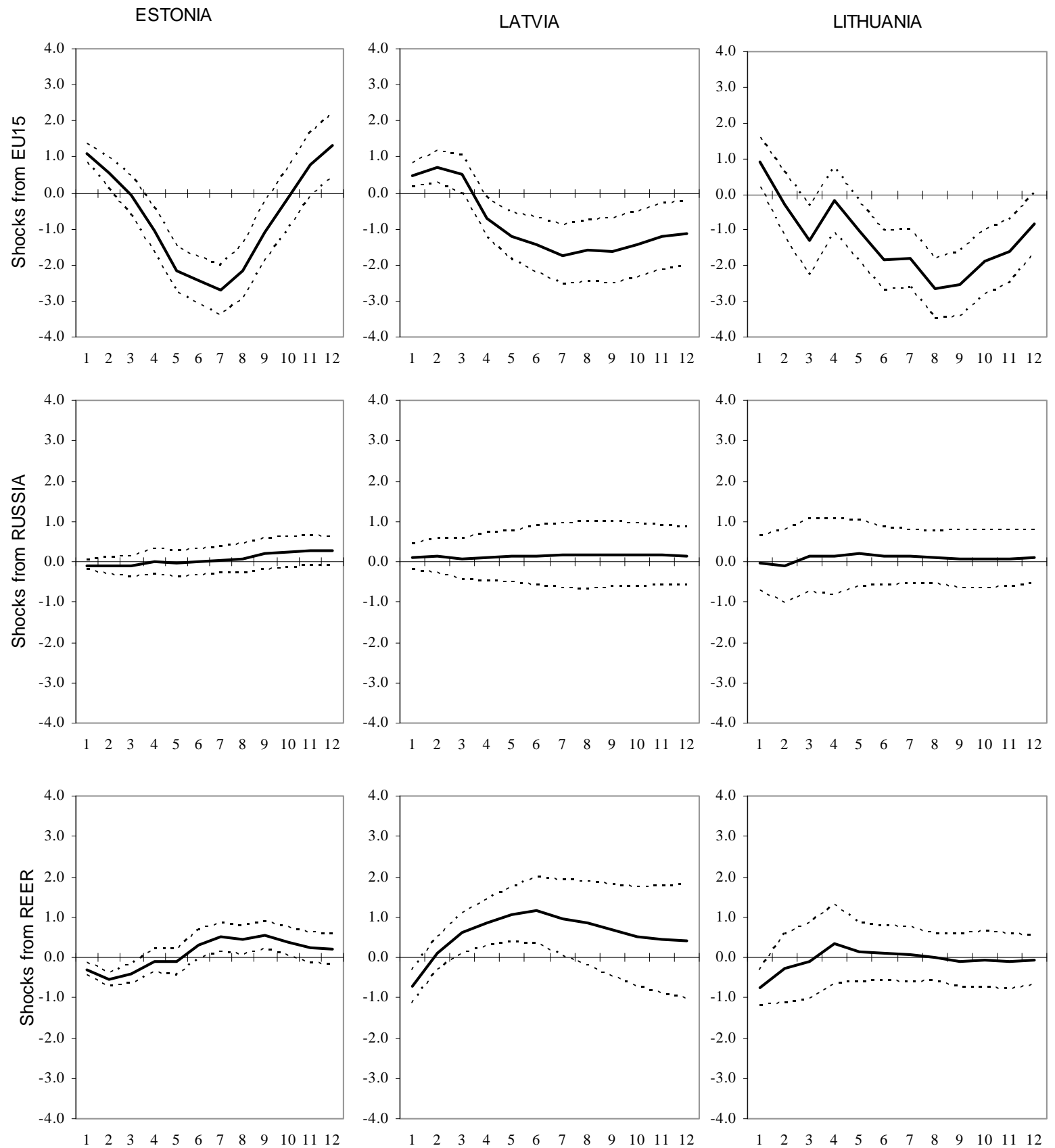

Source: IMF staff calculations. 
Figure A3. Impulse Response Results

(Extended VAR Models, 1996-2007)
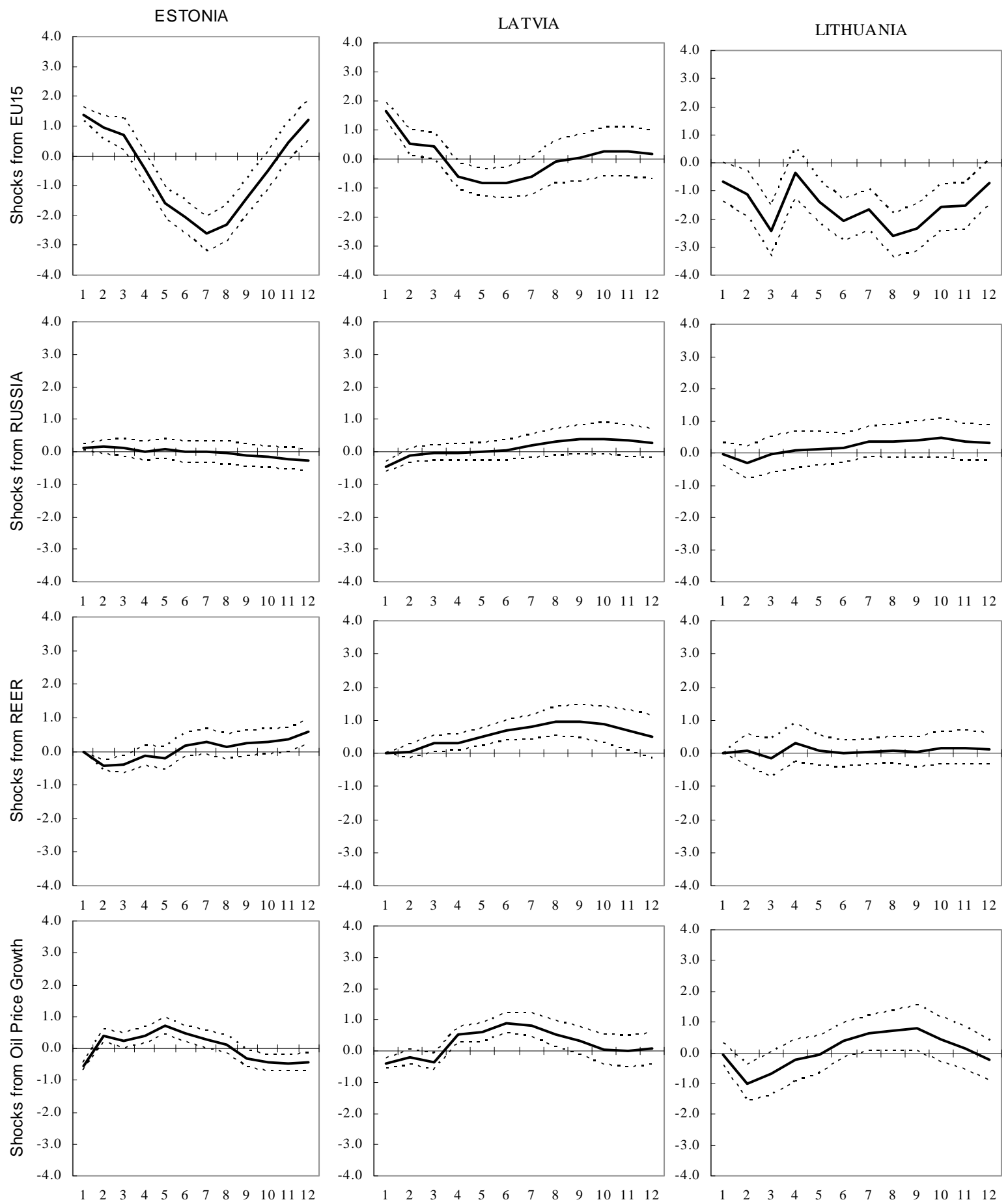

Source: IMF staff calculations. 
Figure A4. The Baltics: Responses to 1 Percent Shock from the Scandinavian Region
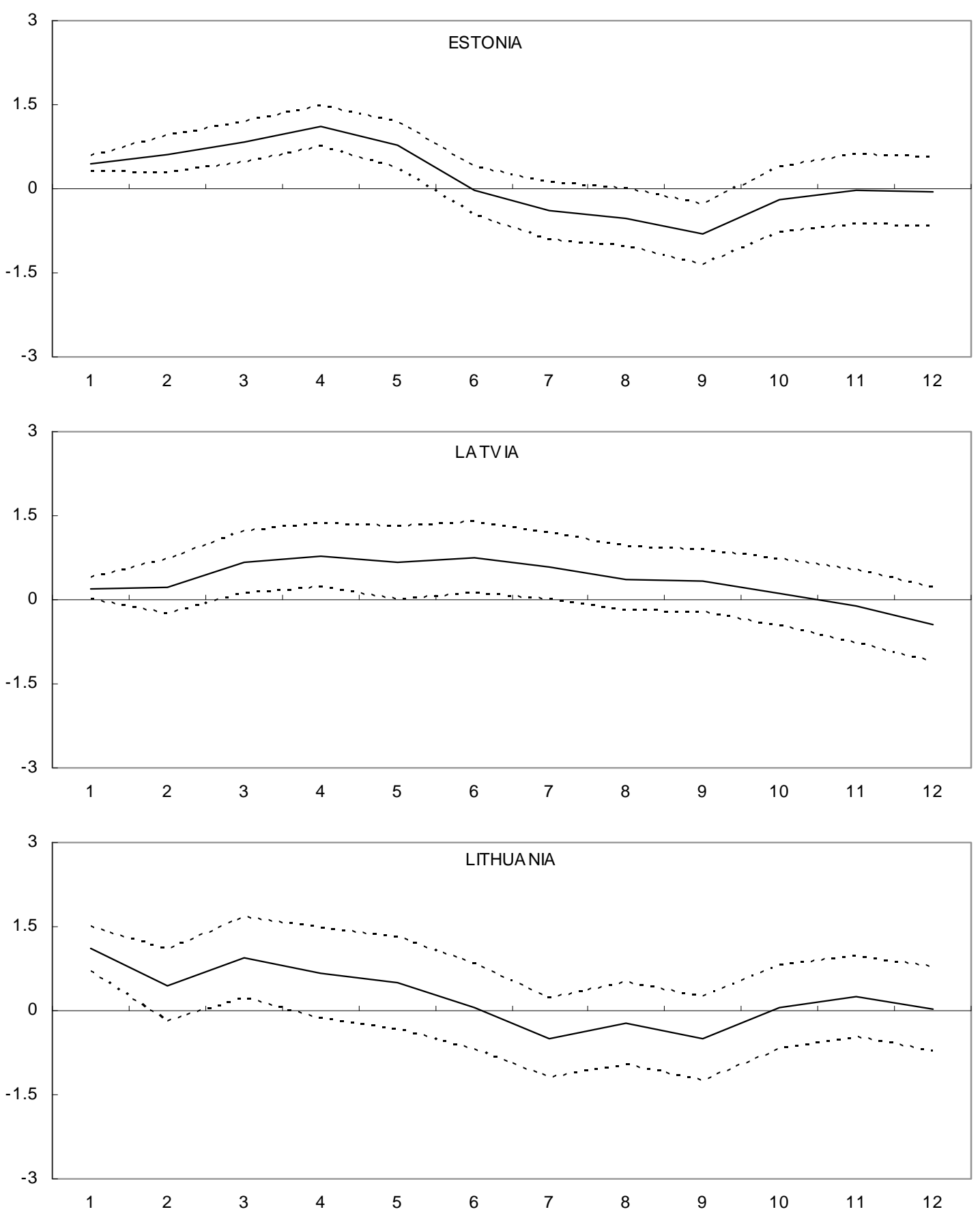

Source: IMF staff calculations. 